\title{
KEATS AS A READER
}

by

\author{
Alexandra Paterson
}

A thesis

submitted to the Victoria University of Wellington in fulfilment of the requirements for the degree of Master of Arts in English Literature

Victoria University of Wellington

2010 


\begin{abstract}
This thesis examines the poetry of John Keats through an exploration of his attitude towards reading.

Keats's reading is characterized by openness, receptivity, and crucially, response. The first chapter explores the dynamics of this by analyzing some early sonnets about his reading within the greater context of this thought as he lays it out in his letters. For Keats, the poetic process, which includes both reading and writing, is an organic one.

The second chapter considers his mediated reading, looking first at the Chapman's Homer sonnet as a celebration of translation and the social reading experience. This leads into a greater exploration of Keats's friendships and sociability, which are not only fundamental to him, but which also play an important role in his reading and poetry. The chapter considers the dialogue that occurs within Keats's marginalia, with his friends, and with the books and authors he reads. This dialogue illustrates Keats's positive relationship with mediation and influence. The theatre in particular is a site of sociability and adaptation, and, for Keats it is also a platform for poetic voice.

The third chapter expands on the importance of the aural experience of reading for Keats, primarily through an examination of "mistiness," a term Keats uses to describe a positive mediated reading experience in a letter to John Hamilton Reynolds. Keatsian mist is a state of mind which, while obscuring one sense usually visual - amplifies the aural sense and imagination.

The fourth chapter comprises an analysis of Keats's poetry of 1819 in order to explore questioning as a creative mode of reading, and silence as an ideal site for the growth of the creative imagination. "To Autumn" presents the culmination of Keats's reading in an affirmation of his own poetic voice.
\end{abstract}




\section{ACKNOWLEDGEMENTS}

My first thanks go to my supervisor, Dr. Heidi Thomson, for her guidance and encouragement.

I would also like to thank Victoria University of Wellington for awarding me a Summer Research Scholarship during the completion of this thesis.

I am extremely grateful to Dad and Sarah R. for their keen proofreading eyes, to Sarah C. for vital coffee breaks and conversation, to my officemate, Ivy, who heard a lot about Keats, to Gareth for being there, to Mum, and to the rest of my family and friends for their support. 


\section{CONTENTS}

Introduction: "The Picture of Somebody Reading".

.1

Chapter 1:

Reading, Receptivity, and Response in Keats's Early Sonnets

Chapter 2:

“Delighted Stares": Keats’s Mediated Reading...

30

Chapter 3:

"Loud and Bold": Keats Reading through Mist.

Chapter 4:

Questioning, Silence, and Creative Stimulation in Keats's Poetry of 1819 .72

Bibliography. .102 
Introduction: "The Picture of Somebody Reading"

In an 1819 letter to his sister Fanny, John Keats imagines "a handsome painted window" looking out "onto the Lake of Geneva," where he could "sit and read all day like the picture of somebody reading" (Letters 2: 46). Keats's own keen awareness of the importance of reading to his poetic life is reflected throughout his letters and poetry, and there has long been a critical interest in his reading and influences.

Not all references to Keats's reading have been friendly. John Lockhart, for instance, in his August 1818 review in Blackwood's Edinburgh Magazine, ridiculed Keats for "know[ing] Homer only from Chapman" (522). Lockhart's rash, but highly quotable, emphasis on what Keats had not read - namely, the original Homer - has struck a chord with many critics, who have drawn attention to Keats's lack of a classical education ever since. The review, writes Nicholas Roe, who debunks the notion that Keats had a poor education, "has been a principal source for the myth of Keats's 'poor' education and 'lower-class' background” (10).

Keats's friends had a clear sense of the importance of his reading. Upon Keats's death in 1821, Charles Brown wrote a list of the books Keats owned, which is reprinted in The Keats Circle (Rollins 1: 253-60). "Chaucer, Spenser, and Shakespeare were his household gods," Brown would write years later (Rollins 2: 56). In an 1849 letter, Benjamin Bailey remembers introducing Keats, who was then "far more enamoured of the beauties of Spenser," to Paradise Lost (Rollins 2: 283). Leigh Hunt wrote that Keats "understood [Chapman] thoroughly" (250).

Charles Cowden Clarke, however, offers the most detailed account of Keats's reading. In Recollections of Writers, he remembers the vigour and momentum with 
which Keats read. He writes that at Enfield School Keats "occupied the hours during meals in reading. Thus, his whole time was engrossed ... He must in those last months have exhausted the school library" (123). Clarke then lists the books the library comprised, including travel accounts, Robertson's histories, the works of Maria Edgeworth, and books on Greek mythology. He writes that Keats even "translated in writing a considerable portion" of The Aeneid (124). He remembers introducing a sixteen-year-old Keats to Spenser (125), and when Keats borrowed The Faerie Queene from Clarke, "he went through it ... as a young horse would through a spring meadow - ramping!" (126). Clarke details Keats's now famous introduction to Chapman's translation of Homer (129-31), his first encounter with Chaucer (139), and recalls Keats's "profound reverence for Shakespeare" as evidenced in letters and memoirs of the Keats circle (156).

The major biographies trace Keats's reading from his schooldays to his death, connecting his poetic study with events in his life, his moods, his friends, and his poetry. In this thesis I refer frequently to Walter Jackson Bate's 1963 biography, and Robert Gittings's 1968 one.

Recently, there has been a surge of historical studies on reading in the Romantic period. William St. Clair, for instance, is interested in the social, political and cultural effects of reading. Unlike most of my other sources, his book, The Reading Nation in the Romantic Period (2004), does not have a literary focus. Skeptical of anecdotal evidence, St. Clair examines the idea that "[r]eading helped to shape mentalities and to determine the fate of the nation" (1), based on the hard evidence of print histories, catalogues and private manuscripts (14-15). In the chapter "Reading, Reception and Dissemination," he discusses some of the individual readers of the time, but for the most part, his focus is broader; " $[\mathrm{t}]$ he whole literary 
system," he argues, "has to be conceived of as existing within wider historical contexts" (8). Of particular interest to my research, though not unique to St. Clair's study, is the exploration of the social aspects of reading, which, in a discussion of Keats's reading habits, cannot be overlooked.

H. J. Jackson's focus on textual annotations and markings in Marginalia: Readers Writing in Books (2001), and Romantic Readers: The Evidence of Marginalia (2005), is equally illuminating. She draws her conclusions from an exhaustive range of marginalia, exploring individual reading habits and their social implications. The chapter "Socializing with Books," in Romantic Readers, includes a fourteen-page section on Keats, in which Jackson emphasizes Keats's sociability in reading, commenting on the notes he wrote for his friends in books, as well as his "intense sympathetic engagement with the author" (193). Many of the readers Jackson focuses on are also authors, and she draws attention to the way that marginal writing "synthesizes ... the functions of reading and writing" (Marginalia 90). The introduction to Romantic Readers comprises an overview of the "reading environment" (1) of the Romantic period, in which Jackson makes some similar observations to those of St. Clair. Like St. Clair, she emphasizes the social aspects of reading, but she also illustrates the significance of marginalia in demonstrating the Romantic awareness of reading being a "common experience" (12).

Lucy Newlyn addresses the conception of readership in the Romantic period in Reading, Writing and Romanticism: The Anxiety of Reception (2000). Her discussions of sympathetic readers, readers' "integrity of the self" (312), and reading aloud have been particularly useful to my project.

In "An Ethics of Reading: A Conflicted Romantic Heritage" (2008), Anthony John Harding, like Jackson and others, highlights the social aspects of reading. In 
particular, he is interested in the shift to a cultural awareness of the new availability of reading material across the class spectrum (56). He also underlines the important role sympathy plays in Romantic theories about reading, including the connection between sympathy and the imagination. He focuses largely on the writings of Adam Smith here, although he also draws a parallel between Smith's ideas and William Hazlitt's. He paraphrases Smith’s argument that “[a]nother person's bodily suffering ... does not in fact arouse our sympathetic feeling so much as those favourite subjects of tragedy, the misfortunes of kings and lovers" (51). Harding is less concerned with individual readers, however, than with the "philosophical context [that] arguments about the expansion of reading" fit into (51).

H. J. Jackson was not the first to make use of Keats's textual annotations. Amy Lowell's 1925 biography includes some of Keats's marginal notes in an appendix. The Hampstead edition of Keats's works, edited by Harry Buxton Forman (1939), also includes marginalia. Caroline Spurgeon reproduces marginalia and some facsimile pages in her 1928 edition of Keats's Shakespeare. Joseph Anthony Wittreich, Jr. in 1970, and Beth Lau more recently, in 1998, have published Keats's Paradise Lost marginalia. Both Spurgeon and Lau include in their books in-depth analyses of the marginalia; Lau also incorporates a general discussion of Romantic marginalia, which Jackson's subsequent work has complemented nicely.

The critical interest in Keats's literary influences extends far beyond the scope of this overview. George Gilfillan, in 1845, wrote that Endymion is "[s]teeped in Spenserian imagination" (304). In an 1854 essay, James Russell Lowell observes what he characterizes as a critical commonplace, that Keats's "poems take the color of the authors he happened to be reading at the time" (361). As Jack Stillinger points out in the Keats chapter of The English Romantic Poets: A Review of Research and 
Criticism (1985), “[e]verybody for one reason or another ... has been interested in Keats's sources" (698). For this reason I do not attempt an exhaustive overview of the critical work on Keats's influences; this thesis itself is not an influence study, but an exploration of the poetic dialogue that Keats's textual encounters produce. Many of these studies, however, have been valuable to my research.

The most in-depth study of Shakespeare's influence on Keats so far has been R. S. White's 1987 book, Keats as a Reader of Shakespeare, which makes use of Keats's marginalia, letters and poetry in order to explore "what Keats himself thought 'Shakespearean' poetry meant to him” (7). White carries on the tradition begun by Spurgeon and John Middleton Murry in his interest in Keats's Shakespearean influence. I put Murry in this category, although as White rightly notes, his Keats and Shakespeare (1925) is more accurately a "literary biography" than critical analysis (18). His study of "the strange relation between [Keats] and Shakespeare" (Murry 5) has, however, been influential. White's study is grounded in an exploration of Keats's reading attitude. He notes that for Keats, "[r]eading provides ... a simultaneous continuum between passivity and active creation, between self-annulment and self-absorption" (21), and he makes the connection between reading and writing for Keats explicit when he indicates that "reading Shakespeare is an involved act of re-creation" (29). He provides a broader context for Keats's thought in a chapter on Hazlitt, Keats and Shakespeare, acknowledging Hazlitt's role as a mediator of Keats's reading of Shakespeare. His primary concern, however, is to explore Shakespeare's influence on Keats's thought, and by extension, his writing.

William Flesch (1995) is also interested in Keats and Shakespeare, although his paper has a much narrower focus: the influence Keats's reading of Antony and Cleopatra had on "To Autumn." Flesch notes that his reading of the poem as Keats's 
escape from the influence of Shakespeare may be "counterintuitive" (150), but he also brings to his discussion an understanding of Keats's responsiveness in reading, and his paper is at the very least a springboard for thinking about "To Autumn" in terms of reading.

Theodore B. Leinwand's “On Sitting Down to Read Shakespeare Once Again" (2002) is the most recent of the studies of Shakespeare's influence on Keats that I have read, but while it paints an enthusiastic picture of Keats as a reader, it does not offer anything new.

Milton's influence on Keats has attracted a significant amount of critical scrutiny. Studies on Milton's influence are largely focused on Paradise Lost, and have, since Harold Bloom's Anxiety of Influence: A Theory of Poetry (1973), nearly always addressed the problem of "anxiety of influence." Lucy Newlyn steps away from this theory in Paradise Lost and the Romantic Reader (1993) by "stressing reader interpretation, as opposed to authorial intention" (5) in her study of the Romantic reception of Paradise Lost. In Keats's Paradise Lost, Beth Lau writes that "if the Romantic poets were oppressed by the burden of the past and anxiety of influence, they were not crippled by it" (21), and she substantiates this claim through a comprehensive discussion of Keats's Paradise Lost marginalia.

Jonathon Shears writes about Keats's narrative poetry in The Romantic Legacy of Paradise Lost (2009). Unlike Newlyn, who concentrates on the reception of Milton's epic, Shears is more interested in authorial intent, as is suggested by his recurring argument that Romantic readers were "reading against the grain."

Timothy Webb treats the Romantic reception and conception of Homer, "the great poetic father" (287) in "Homer and the Romantics" (2004). He weighs Romantic opinions on Pope's and Chapman's translations of Homer, the latter of 
which was generally preferred for its own poetic merit. In his discussion of Chapman's translation, he includes Keats as a "notable example of the Greekless reader" (303). Where Lockhart dwelt on social and class issues, Webb emphasizes Keats's "celebration of the power of translation" (304).

William Hazlitt's influence on Keats has been examined by Kenneth Muir. In "Keats and Hazlitt" (1951), Muir makes great use of Keats's letters in order to "show that nearly all Keats's theories about poetry were developed from remarks of Hazlitt" (158). "Developed" is a well-chosen word, for as Muir is careful to point out, Keats is not simply an "imitator of Hazlitt" (142), but he considers and transforms Hazlitt's theories, and sometimes even "strikes deeper" (143) in the process.

Beth Lau's 1991 book, Keats's Reading of the Romantic Poets, elucidates the literary relationship Keats had with major contemporaries. Lau does not analyze particular influences, but clearly lays out all of Keats's allusions to Wordsworth, Coleridge, Byron and Shelley. In her introduction, she also notes the "significant role" that many of Keats's friends played "in introducing Keats to various works and helping him to develop his opinions about contemporary poetry" (5).

Keats's social influences are addressed in many sources, including the major biographies and works on Keats's literary influences, such as Lau's. There are some works, however, that take social influences as their primary concern. In Romantic Sociability: Social Networks and Literary Culture in Britain, 1770-1840 (2002) Gillian Russell and Clara Tuite's interest in Romantic sociability goes beyond texts, as they emphasize the sociability that is "found in the theatre, the debating club, the bookshop, or the dining room" (4), underlining the cultural importance of these social spaces. Julie A. Carlson's chapter, "Hazlitt and the Sociability of the Theatre," 
has also been valuable, for Keats's admiration of both the theatre and Hazlitt's criticism is integral to his reading.

The high value Keats placed on friendship is not only suggestive of his openness to social influences on his reading, it is vital to his poetics. Ronald A. Sharp's "Keats and Friendship" (1998) is a fine study on the subject, illuminating not only the influence Keats's friends had on his poetry and reading, but also the importance of such influence. Keats was not only "aware of the importance of friendship," he was "profoundly reflective about its nature" as well (66). Joanna Richardson's The Everlasting Spell: A Study of Keats and His Friends (1963) offers biographical details about Keats's friends, but does not discuss any of the poetry, and is not nearly as useful as Sharp's much shorter chapter. Sharp comments on this himself, distinguishing his own focus, "Keats's larger conception of friendship" (67), from Richardson's. Sharp cites Christopher Ricks as another useful source on friendship in a note to his article (80).

There has been a lot of critical interest in Keats's relationship with Leigh Hunt, who had a formative influence on Keats, but I refer to Hunt only in passing in this thesis. I omit him here partly because his influence is more apparent in Keats's writing and social life than in his reading.

Keats's boyhood education at Enfield School is discussed by a few different critics. In John Keats and the Culture of Dissent (1997), Nicholas Roe discusses the influence of Keats's excellent progressive education at Enfield. He refers to John Bonnycastle's book on astronomy, a frequently-cited source for the "watcher of the skies" (9) and "new planet" (10) in "On First Looking into Chapman's Homer" (37). Roe believes it to be more likely, however, "that Keats's imagination was feeding on the memory of discoveries made at Enfield while playing in the 'living orrery' [a 
model of the solar system in which the planets are played by pupils, orbiting around the sun] or gazing at a planet's bright image through the school telescope" (37).

Keats may not have had a classical education, but he certainly had a good one. Enfield encouraged Keats's individual study; Clarke, for instance, remembers Keats winning prizes awarded to "pupils who had performed the greatest quantity of voluntary work" (122). He continued this study through reading for the rest of his life, but his ability and inclination towards self-motivation in his studies was evident as far back as his time at Enfield School.

In “'Cortez - or Balboa, or Somebody Like That': Form, Fact, and Forgetting in Keats's 'Chapman's Homer' Sonnet” (2002), Charles Rzepka brings in Keats's Enfield reading to support an argument that Keats knew the history of the Americas too well for the substitution of Cortez for Balboa in the Chapman's Homer sonnet to be, as many have believed, a mistake. Rzepka also highlights the openness and responsiveness that characterizes Keats as a reader, and the imaginative stimulation this produces.

As Donald C. Goellnicht makes clear in his 1989 article, "Keats on Reading: 'Delicious Diligent Indolence,"” reading, for Keats, is a two-way process. Goellnicht acknowledges that Keats did not put forward any conclusive "theoretical statements" (192-93) about reading or poetics, and is aware that "any attempt to discover in his letters a formulated system of poetics is doomed to failure from the start" (193). He therefore lays out what he terms "a pragmatics, rather than a grammar, of [Keats's] reading" (193). His primary focus is on just one letter, to John Hamilton Reynolds in February 1818, which allows for a deep exploration of Keats's thought about reading, with implications that extend much further than the letter itself. 
Some long studies not directly related to Keats's reading have also been useful. Stuart Sperry's Keats the Poet (1973) is vital, for in exploring Keats as a poet, Sperry recognizes the importance of reading to Keats's creative process. He writes: “[Keats's] conception of the poetic process must be extended ... to include the manner in which poetry operates on other minds - those of its readers - in achieving its effects, for Keats visualizes the two processes as analogous and inseparable" (54). As in criticism that approaches Keats from a historical social context, Sperry emphasizes the importance of the shared reading experience for Keats. Poetry, he writes, "constitutes a form of communication, the way different minds progressively corroborate, assimilate and extend the primitive experience they share in common" (55).

Although Leon Waldoff does not talk about reading specifically, in Keats and the Silent Work of the Imagination (1985), he notes that "Keats ordinarily makes no distinction between the uses of imagination in the response to art and in the creation of it" (4). Keats's reading and the creation it inspires are part of the same process, and that is why an understanding of Keats's imaginative capabilities is integral to an understanding of his reading. Waldoff considers the Letters in his exploration of Keats's imagination, before applying his understanding of the working of Keats's mind to a discerning reading of the poems.

Susan J. Wolfson has a narrower focus in The Questioning Presence: Wordsworth, Keats, and the Interrogative Mode in Romantic Poetry (1986). Questions in Keats's poetry spur imaginative creativity, and the connection between questioning and the imagination is made clear in Wolfson's opening sentence: “The activity of questioning sets the mind against itself, the energy of that opposition driving new expansions of thought or nervous efforts at containment" (17). These 
"new expansions of thought" are particularly applicable to Keats's reading, and although Wolfson's discussion of self-inquiry and doubt is also interesting, it is her discussion of interpretation in Keats, particularly in "La Belle Dame Sans Merci," that has been most valuable to my study.

While the influence of Christopher Ricks's Keats and Embarrassment (1974) is less specific than my other sources, it is nonetheless indispensible for Ricks's insightful reading and awareness of Keats's sensibility. Keats's own awareness and invocation of all the senses is a crucial part of his reading process, and with a focus on embarrassment, and often blushing, Ricks elucidates the relationship of the senses to Keats and to each other.

The last four books I have cited illustrate the potential for a broader definition of reading. As White writes of Keats and Shakespeare, "[b]y interpreting the evidence of the ways in which Keats understood Shakespeare, we find ourselves in some limited but real way recreating the mysterious process of reading itself' (21). Similarly, I attempt to read Keats's reading as he himself describes it in his letters and early sonnets. I explore Keats's reading process, as it is related to his creative imagination, and use my findings as a lens through which I read his later poems.

My broad definition of reading includes the cognitive stimulation of listening and seeing, as well as questioning and interpreting, and the texts that can be read include music, as in the Nightingale's song, and art, such as the Grecian urn. Keats invites sensation, mediation and influence in his reading, and this openness extends to his writing. Like Goellnicht, I am interested in the "pragmatics" of Keats's reading and writing processes, and I do not aim for an exhaustive or conclusive discussion of such a rich topic. Having acknowledged the large body of scholarship behind me, I now turn towards a primary reading of the texts: Keats's letters, sonnets, and great 
odes, as well as "The Eve of St. Agnes" and "La Belle Dame Sans Merci." Longer poems such as Endymion, Hyperion, and The Fall of Hyperion I have left out of my reading due to constraints of space.

All of my poetry references are to Jack Stillinger's edition of the Poems (1978), and references to the poems' textual histories come from Stillinger's The Texts of Keats's Poems (1974). All references to the Letters come from Hyder E. Rollins's standard edition (1958). 
Reading, Receptivity, and Response in Keats's Early Sonnets

Of the poems in Keats's first publication, Poems (1817), "On First Looking into Chapman's Homer" stands out as a masterpiece. Helen Vendler calls it Keats's first "perfect" poem (Coming of Age 1, 55), and labels it "strikingly mature" (44) in the context of the 1817 volume. It also marked a turning point in Keats's career. As Robert Gittings writes, the sonnet "has an authority never heard in Keats before" (129). It was written shortly after Keats returned from his largely unsuccessful stay at Margate, where he had hoped to write poetry away from the city. After several weeks, however, he returned unsatisfied, having written little (Bate 82). It was only shortly after his return that poring over Chapman's Homer gave him the impetus he needed to write (Bate 84-86). Walter Jackson Bate points out that, like the other poems in the collection, "Chapman's Homer" is full of borrowings, and "[e]very possible echo ... of Keats's reading has been exhaustively traced" (88). What is different about this sonnet is that it reproduces, as Charles Rzepka writes, not only his reading experience but also the "feeling of the sublime" (72, original emphasis). In a poem saturated in images of exploration and discovery, Bate argues that the most significant of Keats's discoveries is not that of Homer, but that of his own poetic ability, and the confidence he is able to draw from it (89). Keats not only discovered his ability to write great poetry, however; he also surmised the extent to which his reading could contribute to the production of it.

Although it is a poem about a reading experience, the various words Keats uses to describe his reading in the Chapman's Homer sonnet do not include any variation on the verb "to read." Reading is likened to "travell[ing]" (1), and in addition to motion, Keats's aural and visual senses are invoked. He "hear[s]" (8) 
Chapman speak, instead of reading him. A visual metaphor for reading is introduced in the title, "On First Looking into Chapman's Homer," and is maintained throughout the poem: he describes the works he has "seen" (2) and compares himself to both a "watcher of the skies" (9) and Cortez, who "star'd at the Pacific" (12). The importance given to the visual metaphor by its inclusion in the title is cemented by the final image of the poem, that of Cortez looking out over the Pacific. Yet it is the act of breathing, which is introduced in the seventh line, that makes this particular reading experience unique. David Ferris highlights the significance of breathing, noting that although the speaker hears Chapman's voice first, it is breathing that is introduced first in the poem, at line 7 (72). The emphatic " $[t]$ hen" of line 9 also suggests the importance of inhaling as a catalyst for the sublime effect of his reading:

Yet did I never breathe its pure serene

Till I heard Chapman speak out loud and bold:

Then felt I like some watcher of the skies

When a new planet swims into his ken; (7-10)

Hearing Chapman's voice allows him to "breathe [the] pure serene" of Homer, but it is the breathing itself that produces the sublime experience. In an 1818 letter to John Taylor, Keats writes that poetry's "touches of Beauty should never be half way thereby making the reader breathless instead of content" (Letters 1: 238). Great poetry, for Keats, was vitally connected to breathing.

The notion of inhaling the essence of Homer reflects contemporary ideas about reading canonical authors. In Reading, Writing and Romanticism, Lucy Newlyn discusses Thomas Noon Talfourd's writing on the idea of poetic genius. Talfourd felt that the genius of "influential authors" such as Milton and Wordsworth was " "pervading every part of the national literature"” (qtd. in Newlyn 312). "Their 
spirits," Newlyn explains, "abstracted from individual identities, are believed to mingle with the "intellectual atmosphere"" (312). Keats felt Shakespeare mingling in the atmosphere around him. In an 1817 letter to Benjamin Robert Haydon he writes, "I remember your saying that you had notions of a good Genius presiding over you I have of late had the same thought ... Is it too daring to Fancy Shakespeare this Presider?" (1: 141-42). In the "Mansion of Many Apartments" letter of May 1818, he hints at a sort of intellectual atmosphere when he writes that "we become intoxicated with the light and the atmosphere" in the "Chamber of Maiden-Thought" (1:281). The "Chamber" is a stage of human intellectual development, and one becomes "intoxicated" within it by breathing in the surrounding atmosphere. "[A]mong the effects this breathing is father of," Keats continues, "is that tremendous one of sharpening one's vision into the [heart] and nature of Man" (1: 281). Just as in the Chapman's Homer sonnet, inhaling the sublime atmosphere awakens visual faculties. In the sonnet, Keats's simile for reading is a literal vision, as Cortez looks out over the ocean. The letter, on the other hand, written one and a half years later, depicts a vision that turns inward, and observes "Misery and Heartbreak, Pain, Sickness and oppression" (1: 281), a stark contrast to the awe and wonder of the sonnet. It indicates a change in the way the mature Keats inhales poetic sublimity, in that it incorporates suffering, which I will discuss in the final chapter. The importance, however, of a sense of an "intellectual atmosphere" for him to breathe in, even early in his career, is clear.

Breathing is an appropriate metaphor, for an inhalation necessitates the response of an exhalation. Keats inhaled poetic power by reading Chapman's Homer, and exhaled it by writing the "Chapman's Homer" sonnet. As Kenneth M. Mason, Jr. puts it, the sonnet is an "exhalation of the 'pure serene' Chapman's language has 
oxygenated" (7). Keats recreates the sublime experience for his readers. As Rzepka describes this phenomenon, "the writer who takes as his subject another's sublime writing can become so intoxicated by it that his text demonstrates what he describes, inducing sublime intoxication in his readers" (73). This transfer of sublime intoxication is a result of not only "'being possessed' by the immediate power of what is read or heard" (72) but also of the poet's "opening himself up to being possessed ... by his predecessor's ghostly presence" (74, original emphasis). "Opening up" here is key, for it necessitates an active role on the part of the reader. The passivity of "being possessed" is counteracted by the fact that Keats must invite intoxication or possession by the text, and so he "breathe[s] its pure serene" (7).

Rzepka's phrase, "sublime intoxication," recalls the atmospheric intoxication of the "Chamber of Maiden-Thought" (Letters 1: 281). This intoxication is quite unlike alcoholic inebriation; far from the oblivion the speaker of "Ode to a Nightingale" craves through wine, "sublime intoxication" fills the reader with awareness, what R. S. White calls a "feeling awareness" (26) of the sublime within the poetry. This awareness is marked by responsiveness, which in turn prompts Keats's writing. Donald C. Goellnicht addresses Keats's criticism of Wordsworth in an 1818 letter to Reynolds, in which Keats complains that poetry like Wordsworth's "has a palpable design upon us" (Letters 1: 224), and does not allow the reader enough scope for response (“Keats on Reading” 202). For Keats, Goellnicht writes, "reading is not a matter of the reader's mind being taken over by or occupied with the thoughts of the author, as he believes Wordsworth would have it" (204). The reader must be allowed to formulate his or her own response.

An interesting point of comparison here is the reading mind of Charles Lamb. Newlyn discusses Hazlitt's description of Lamb as a reader-writer, saying that he is 
“"so thoroughly imbued' with the authors he admires that, instead of being a vehicle (or, as Keats would put it, a 'thoroughfare') for their voices, they provide a 'form of conveyance' for his" (Reading, Writing, and Romanticism 178). In his essay, "Detached Thoughts on Books and Reading," Lamb writes, "I dream away my life in others' speculations. I love to lose myself in other men's minds. When I am not walking, I am reading; I cannot sit and think. Books think for me" (172). While some room must be given here for Lamb's humorous tone, his comments still illustrate an approach to reading that differs from Keats's in the extreme. For Keats, the response of the reader is equally as important as the text itself; for Lamb, the reader appears to be entirely passive. Losing himself in the text, Lamb is completely under the influence of it, and entirely selfless. For Keats, however, sublime intoxication leaves room for creative thought, as his own breath mingles with the "intellectual atmosphere." Keats liked the idea of "Lovers of Poetry" having "a little Region to wander in where they may pick and choose" so much that he copied out the thought to both his brother George and Benjamin Bailey in October 1817 (Letters 1: 170). Keats wanders through books but does not lose himself; picking and choosing, he remains self-aware, and his own identity remains intact. As a poet, Keats rejects the idea of an individual self; the negatively capable poet is selfless. As Stuart Sperry writes, however, "poetry was ideally a form of self-discovery each reader had to carry out in the light of his own unique experience" (60), and for Keats as a reader, a distinct, albeit responsive, identity is necessary.

Rzepka draws attention to Hunt's assessment of the Chapman's Homer sonnet, in which 'Keats 'announc[es] himself as a new poet taking possession' of his literary fiefdom" (71). He does not dwell on the fact of Keats's "taking possession," his argument focusing on his "being possessed." In order to fully appreciate the 
effect of Keats's inhaling the sublime power of Homer, however, we must account for both the taking and the receiving of possession; Keats responds to being possessed by both Chapman's and Homer's "pure serene" by taking possession of his own. He does this not by, as Daniel Pollack-Pelzner suggests, "revis[ing] an earlier poet's scene to place himself within it" (42), but by bringing the sublime feeling that he reads into his own experiences. Rzepka quotes Andrew Motion on the “exceptional and suddenly found maturity" of the Chapman's Homer sonnet, which "depends not on Keats escaping the tensions which shaped his personality, but on incorporating them" (71). It is not about revising another poet's work, but using the other poet's sublime influence to revise his own. White points out something similar in discussing the way Keats re-interprets images he has read in Shakespeare for Endymion: "Keats is not simply echoing but interpreting ... or ... amplifying the scope of an image from a single word to a more comprehensively visualized scene" (107). Keats transforms poetic influence into an enhancement of his own poetic vision.

Bate writes that the Chapman's Homer sonnet gave Keats a newfound confidence in his poetic abilities (89). The revision of the seventh line before the poem's publication suggests that at least part of this confidence stems from his aware and responsive reading. In an earlier draft of the poem, the seventh line read "[y]et could I never judge what Men could mean" and Keats retained this wording for the poem's initial publication in the Examiner in December 1816 (even though he made another revision at the time: replacing Cortez's "wond'ring eyes" with "eagle eyes"). It was not until Poems that the seventh line became "Yet never did I breathe its pure serene" (Stillinger, Texts 116-17). The line is the most suggestive in the entire sonnet of Keats's awareness of the reading-writing process, and it is perhaps significant that 
it was included in the poem only after he had good reason to believe in its success; namely, its publication in the Examiner, and praise by Leigh Hunt among others (Bate 91). He breathed in the essence of Homer, combined it with his own poetic powers, and it worked; he was now able to say with confidence that he breathed its "pure serene."

The response that was aroused in Keats by his reading of Chapman's translation extends further than the Chapman's Homer sonnet. His avid and active reading can be seen as a kind of "opening up" to the possession of many great writers. In looking at Keats's marginalia, H. J. Jackson finds that he "marked a Shakespeare as he studied the plays with a view to improving his own writing," which also suggests his openness to possession by the poets he admired (Romantic Readers 253). In opening himself up to the sublime power of Shakespeare, he hoped to learn from him. If in "Chapman's Homer" Keats realizes the success of his breathing in the pure serene of past poetry, in “On Sitting Down to Read King Lear Once Again” he acknowledges its success by formalizing his plan to read Shakespeare in the same way. This was not the first time Keats had formalized his writing process in his poetry: the Chapman's Homer sonnet, according to Hunt, was an announcement of taking poetic possession, and Keats begins Endymion by announcing his plans for writing the poem. "Many and many a verse I hope to write," he declares (1.49), before "autumn bold" (1.55). These, however, are announcements about his writing. The King Lear sonnet is the first time he makes such a bold declaration of his plans for reading.

In a letter of 23 January 1818, Keats tells his brothers, "I sat down yesterday to read King Lear once again the thing appeared to demand the prologue of a Sonnet, I wrote it \& began to read" (1: 214). The "thing" that demands a prologue is not King 
Lear itself, but Keats's reading of it, which was an undoubtedly momentous event. Bate notes that Keats's "imagination was increasingly haunted by King Lear" (158), and now that he had finished the test of Endymion, he could devote himself to the next step in his poetic career, which would involve reading "intensively" (Bate 294). In "Sleep and Poetry" Keats wished "for ten years, that I may overwhelm / Myself in poesy; so I may do the deed / That my own soul has to itself decreed" (96-98). He would start by overwhelming himself in Shakespeare.

In the King Lear sonnet, Keats addresses Shakespeare and the "clouds of Albion" (9), asking "when I am consumed in the fire, / Give me new phoenix wings to fly at my desire" (13-14). He is referring to, as his "[a]dieu!" (5) to "goldentongued Romance" (1) suggests, a new direction in his poetry. He plans to "burn through" the play (7), to the point of being "consumed" (13), and it is then that he will receive his "new phoenix wings" (14) - a new poetic self, explicitly associated with his reading. In “Oh! how I love, on a fair summer's eve," Keats refers to the "wing of poesy" (12) when imagining his poetic predecessors, and the idea of wings of poesy recurs throughout his works, including "Ode to a Nightingale" (33). The "phoenix wings" are wings of poesy, and in the sonnet, Keats displays his readiness to inherit them. The phoenix image necessarily carries with it connotations of death and rebirth; however, when one considers that the only flames he is consumed in (and it is notable that he is consumed in them and not by them) are those of Shakespeare's own "pure serene," it is clear he is not talking about death. This is a pure serene he has deliberately and thoughtfully read in order to reach. Although he may now lose himself, temporarily, he does so in order to rise back out of the fire as a wiser, better poet. White notes that "[h]e must be burned, as well as burn" (25). Keats will "burn through" King Lear until it burns him back, and "consumed in the 
fire" (13), his own poetic powers will intermingle with that of the "Chief Poet" (9) until they are enriched to the point of forming a new poetic self, not killing the old one, but developing and expanding it.

White draws attention to the idea of the new poetic self when he explains the "mode of thought" behind Keats's persistent treatment of "the related subjects of reading, writing and living":

Complete submission to external impressions, complete immersion in the flux of experience, lead to a feeling awareness of the dark and light in human existence, and out of this knowledge, phoenix-like, emerges a fully responsible, compassionate and self-aware identity, (26)

It is the emergence of this "self-aware identity" that concerns Keats in the King Lear sonnet, and it is the meeting of his openness to poetic possession with the "pure serene" of poetry that gives birth to it. Newlyn, in her discussion of Talfourd, cites a "paradoxical theory of reading" in the Romantic period, "in which no amount of openness to the ideas of others could threaten the integrity of the self" (312). Keats's self-awareness in his reading allows him to maintain his own identity.

In the King Lear sonnet, Keats announces his plans to read in order to give birth to a new, or greater, poetic identity. He often links his reading to creativity in his early poetry, and it is always in the context of plans for the future; in reading, he is preparing himself for future creativity. "When I have fears that I may cease to be" continues the theme of giving birth to poetic power. The poem begins:

When I have fears that I may cease to be

Before my pen has glean'd my teeming brain,

Before high piled books, in charactry, Hold like rich garners the full ripen'd grain; (1-4) 
"Teeming" is a fertile image that has connotations not only of ripeness, but of birth, and recalls the poetic rebirth of the King Lear sonnet, or of Shakespeare and the “clouds of Albion" (9), who are "[b]egetters of our deep eternal theme” (10). In visualizing his teeming brain, he raises himself to the level of his great predecessor by suggesting that he is (or will be) ready to beget his own theme; the word "teeming" itself implies a readiness to do so. He calls the poetry produced by his poetic self "full ripen'd grain," recalling the ripe "Shakespearian fruit" that is King Lear.

While he does not call attention, in this poem, to the connection of his reading to his writing, it is nevertheless present. The image of the "pen glean[ing] my teeming brain" makes the connection, if we consider, as I am here, that his brain is teeming with readings of his poetic predecessors. His brain is "teeming" from what he has read, and he will "glean" from this in order to write. When we take into account the connotations of birth that "teeming" carries, his gleaning corresponds to the birth of his poetic genius in the King Lear sonnet. It is not surprising that these images should carry over, for "When I have fears" was composed within a week of the King Lear sonnet, when his reading-writing process is likely to have been foremost in his mind.

Keats also composed "Spenser, a jealous honorer of thine" around this time; it is dated 5 February 1818 (Stillinger, Texts 174). In it, he rationalizes the readingwriting process he put forth in the King Lear sonnet by emphasizing the impossibility of diving into a Spenserian way of writing. "It is impossible," he says "to escape from the toil / O' the sudden, and receive thy spiriting" (9-10). On the one hand, this repetition is defensive, offering and then reinforcing his excuse to the "jealous honorer" who requested he write some Spenserian verse. At the same time, however, 
it demonstrates a realistic sense of his own abilities - or at least of the methods that work for him. He has a desire for the kind of poetic genius he admires, including Spenser's, and in the King Lear sonnet he lays out his plan for achieving this. In "Spenser" he restates his method in different words: "[t]he flower must drink the nature of the soil / Before it can put forth its blossoming" (11-12). The wording takes us back as far as the first time Keats successfully breathed in the poetic genius of his predecessors in the Chapman's Homer sonnet. The two metaphors for reading drinking and breathing - work in similar ways, for just as breathing is vital for human life, drinking "the nature of the soil" is essential for the flower's. As Leon Waldoff points out, 'the word 'swims' [in the Chapman's Homer sonnet] ... suggests that the eye is an orifice that can take liquids into it, so that the new planet is drunk through the eyes and then enters into the poet's ken" (79). In 1816, then, Keats was drinking Homer, and two years later, it is still an important metaphor for his reading.

The flower "blossoming" with its own poetic genius recalls the "Shakespearian fruit" of the King Lear sonnet (8), and will become the "full ripen'd grain" of "When I have fears" (4). The imagery suggests that Keats's poetic process is a natural, organic one. This is why it is "impossible" to force. The natural metaphor persists through the recurring theme of literature as a forest, seen in both the King Lear sonnet (“[w]hen through the old oak forest I am gone” (11)) and "Spenser" ("[a] forester deep in thy midmost trees" (2)); the poem "This pleasant tale is like a little copse" continues the theme by likening a story in Chaucer to a small grove in the first line. In the letter to his brothers about the King Lear sonnet, Keats asserts the importance of "a very gradual ripening of the intellectual powers" in order to accomplish "great productions," before continuing on to describe his writing (1: 214, my emphasis). He talks about "ripeness in intellect" in a letter to Reynolds a 
month later (1: 231). In the same letter, he explores reading through various metaphors, including that of the book and reader as bee and flower. " "[L]et us open our leaves like a flower and be passive and receptive," Keats writes (1: 232). Keats's passivity is characterized by the inclusion of receptivity. It is passive only in the sense that the reader is at this stage not a creator, but is actively receiving, absorbing the poetic genius of the work he or she reads. Keats expands the image by describing the flower as "budding patiently under the eye of Apollo and taking hints from every noble insect that favors us with a visit" (1: 232). The passive flower's "budding patiently" suggests a slow and careful poetic growth. It receives by boldly "taking hints." Being "passive and receptive" does not entail simply waiting, inert, for power or wisdom, but rather an active willingness to absorb poetic power and to learn. Keats's use of the term "passive" elucidates his patience - he is prepared to wait for a greater wisdom, instead of "buzzing here and there impatiently from a knowledge of what is to be arrived at" (1: 232). Using the metaphor of the flower and the bee, Keats concludes that, after all, "the receiver and the giver are equal in their benefits" (1: 232).

In The Poet-Physician, Goellnicht writes that for Keats, "the relationship between organic growth and poetic creativity ceases to be simply a neat ... analogy and becomes instead a strong metaphorical identification" (107). When Keats outlines his third axiom of poetry, "[t]hat if Poetry comes not as naturally as the Leaves to a tree it had better not come at all" (Letters 1: 238-39), he does not simply suggest that poetry should be an unconscious outpouring, but that it must be the result of a natural process, which encompasses passivity, receptivity, and patience. It requires, as Keats continues in the letter on the King Lear sonnet, "a sort of

\footnotetext{
${ }^{1}$ Donald C. Goellnicht explores all of these metaphors in great depth and detail in his paper, "Keats on Reading: 'Delicious Diligent Indolence."”
} 
determination \& strength" (1:215). The reader must put in the work. Opening up is not a matter of sitting down with a book and willing the poetic power to come. In fact, as he tells his own readers in "Spenser," that sort of thing is "impossible." In the King Lear sonnet he does not simply read, he "[m]ust ... burn through" (7) and "humbly assay" (7). "Must" gives his reading a seriousness, purpose and necessity; the image of burning through suggests both how thoroughly and how passionately he will read the text; and "humbly assay" suggests an exploration for the purposes of learning.

His 1818 reading of King Lear was such an important undertaking in his poetic schooling that it required a preparatory sonnet, and crucially, in "On Sitting Down to Read King Lear Once Again" Keats documents his preparation for not just a reading of Shakespeare's play, but a re-reading of it. The repetition of the title's "once again" in line 5, and "once more" in line 7 emphasizes the act of revisiting, which is fundamental to the reading event. When Keats writes to his brothers about it, he repeats that he "sat down ... to read King Lear once again" (1:214), and only two months before writing the sonnet he had written to Bailey about the "silent Working" of the imagination, extolling the "rewards" that its "repeti[ti]on" produces (Letters, 1: 185). “[H]ave you never," he writes, by being surprised with an old Melody - in a delicious place - by a delicious voice, fe[1]t over again your very speculation and surmises at the time it first operated on your soul - do you not remember forming to yourself the singer's face more beautiful that [sic] it was possible and yet with the elevation of the Moment you did not think so - even then you were mounted on the Wings of Imagination so high - (1: 185) 
He concedes that "this cannot be exactly the case with a complex Mind" (1: 186) but it nevertheless illustrates the potential for sublime experience that imaginative revisiting holds. The idea of music "operat[ing]" on one's soul is characteristic of Keatsian receptivity, and his description of the imagination's working also includes an element of creative energy, which exemplifies Keats's awareness of the poetic stimulation available through reading. In imagining a singer's face to be more beautiful than it is, one must partially create, "mounted on the Wings of Imagination." Re-reading a text has a similar creative effect. Still addressing Bailey, Keats writes that "the redigestion of our most ethereal Musings on Earth" is "necessary to your eternal Happiness" (1: 186); the word "redigestion" emphasizes the importance of revisiting imaginative experiences. If revisiting one's own imaginative experiences and "ethereal Musings" means they will be "repeated in a finer tone," as Keats writes in the same letter (1: 185), it follows that revisiting what one has read will in turn lead to a reading experience that is also of "a finer tone."

Re-reading prepares the mind for later poetic creativity by storing the ideas it provokes in the poet-reader's mind. The "teeming brain" of "When I have fears" is an appropriate image here. On 23 January 1818, a day after writing the King Lear sonnet, and only some days before composing "When I have fears," Keats wrote another letter to Bailey, in which he considers the intelligent human mind:

Twelve days have pass'd since your last reached me - what has gone through the myriads of human Minds since the $12^{\text {th }}$ we talk of the immense number of Books, the Volumes ranged thousands by thousands - but perhaps more goes through the human intelligence in 12 days than ever was written. (1: 209) He highlights the mind's capacity for processing thoughts, which is so immense that even books cannot match it. Yet even in doing so, he makes the connection between 
the mind and reading once again, with an awareness, perhaps, that reading these books activates the mind which processes so much. For all that the human mind retains, however, the very phrase "goes through" implies an awareness on Keats's part that there is plenty that the "human intelligence" does not retain. This is where re-reading becomes such a useful tool for expanding the mind. Keats himself was aware, and repeated the thought to both his brother George and Benjamin Bailey, that in the best poetry, "the images are so numerous that many are forgotten and found new in a second Reading" (1: 170). The value of any text for the reader increases with every new reading, as new treasures, and new understandings, are discovered each time, contributing to an experience that can only be more profound than the last. As the importance of Keats's reading was increased by the occasion of a rereading, the need to fully prepare himself by writing a sonnet about the experience also became greater. Only two months after writing the letter to Bailey, Keats made a conscious decision to change the way he read by writing the King Lear sonnet. Bate writes that the sonnet itself did not signify a particularly new way of writing for Keats, but that Keats's "attitude was new ... as an active ideal” (293). It marked a conscious decision to change not the way he wrote, but the way he read. In the sonnet, Keats announces his plans to read at an elevated level, with the goal of activating his own poetic voice. In the eight months following the composition of the sonnet Keats did not write much that would, as Bate writes, "illustrate a striking, dramatic development. They were," he continues, "months of preparation" (293). That this preparation was to have a foundation in reading is clear when the King Lear sonnet is read alongside "Lines on Seeing a Lock of Milton's Hair," which was composed at the request of Leigh Hunt only a day before the King Lear sonnet (Bate 285). In "Milton's Hair" he calls it a "mad endeavour" (6) to "offer a burnt sacrifice 
of verse / And melody" (9-10) to Milton. Although the autobiographical speaker looks forward to a time "[w]hen every childish fashion / Has vanish'd from my rhyme" (22-23), he recognizes that at present, the "burning, and the strife" (28) of high poetic attempt is fruitless. "For many years my offerings must be hush'd" (32), he concludes, before he can "speak" with the poetic voice he desires (33). The "burning" that characterizes his writing in "Milton's Hair" becomes the "burn[ing] through" of reading in the King Lear sonnet - a preparation Keats perhaps felt was more appropriate for the great "offerings" to come.

I have already mentioned, in my discussion of the Chapman's Homer sonnet, the importance of both being possessed and taking possession. There is a crucial moment between these two states - the "creative moment" as White calls it, which is the "combination of active engagement and submissive receptivity" (25). The moment relies on the overlap of activity and open, malleable passivity, which can be seen in the contrasts of active and passive action in the sonnets. In the King Lear sonnet Keats turns the play into something consumable by calling it "Shakespearian fruit," and he is in turn consumed by it after actively "burn[ing] through" it. In "When I have fears" the image of his pen gleaning his brain suggests a passive mind, and yet the "teeming" shows his brain to be active. The necessary balance between activity and passivity is at its most obvious in "Spenser": the flower must actively "drink" in order to passively "receive thy spiriting," to which it can respond by "put[ting] forth its blossoming." One "drinks" Spenser in, and in doing so, "receive[s]" poetic genius. This sort of to-and-fro, a mutual exchange of work, highlights not only the organic nature of Keats's reading and writing processes, but the creativity inherent in both. For Keats, Sperry writes, “[p]oetry ... works by arousing in the mind of the reader sensations and associations, a series of 
speculations and inquiries, similar in kind (which is not to say identical with) those through which it has been created" (54). In "Keats on Reading: 'Delicious Diligent Indolence,"” Goellnicht writes that "[w]hatever the reader gains from his poetry must be achieved through a combination of the poet's imaginative expression, as it exists in the text, and the reader's imaginative response" (208). The author and the reader share equal responsibility in the reading process, what Sperry calls "the vital cooperation of poet and reader" (60). In order for the reader Keats to gain poetic power from what he reads, he must not only breathe it in, but respond to it. 
"Delighted Stares": Keats's Mediated Reading

In April 1818, Keats wrote to John Hamilton Reynolds:

I long to feast upon old Homer as we have upon Shakespeare. and as I have lately upon Milton. - if you understood Greek, and would read me passages, now and then, explaining their meaning, 't would be, from its mistiness, perhaps a greater luxury than reading the thing one's self. (Letters 1: 274) This passage epitomizes Keats's openness to mediation and his appreciation of reading as a social activity. The fact that Keats would be encountering Homer second-hand, through Reynolds's reading and explanations, is eclipsed by the delightful prospect of a shared reading experience. In this chapter I explore mediation in terms of this shared experience through a discussion of Keats's friendships, marginalia, and theatregoing.

Keats famously celebrates George Chapman's (1559/60-1634) mediation of his reading in “On First Looking into Chapman's Homer." Chapman was an Elizabethan dramatist, and it is not surprising that Keats, who admired "intensity" (Letters 1: 192) and gusto in any art, responded far more to his text than he did to Pope's more formal and rigid version, which he had encountered a few years before Chapman's (Bate 85). Chapman's translation was admired by other Romantics, too. Samuel Taylor Coleridge, for instance, wrote that "Chapman writes \& feels a Poet as Homer might have written had he lived in England in the reign of Queen Elizabeth" (1120). He also finds that Chapman's Homer "has no look, no air, of a translation" (1119-20), describing it as a "truly original poem" (1120). A note to Coleridge's marginalia quotes Charles Lamb, who goes so far as to say that Chapman "has improved upon" the original (1119). Like Coleridge and Lamb, Keats 
appreciated Chapman as a poet, but, unlike them, he saw Chapman primarily as a mediator of Homer. Thomas Frosch indicates this in a note to "Keats's 'On First Looking into Chapman's Homer.'” Pointing to an 1817 letter Keats wrote to Benjamin Robert Haydon, Frosch writes: "Keats referred to Haydon's copy of Chapman's Homer as 'your Homer,' suggesting that he did not think of Chapman separately from Homer" (149). Timothy Webb attributes part of the Romantic popularity of Chapman's translation to his "captur[ing] much more of the essence of Homer than Pope" (307) and it is this essence of Homer that Keats was looking for, and responded to, in the Chapman's Homer sonnet.

Despite the popularity of Chapman's translation at the time, some, like John Lockhart, took issue with Keats's inability to read the original. In the April 1818 edition of Blackwood's magazine, Lockhart, writing under the moniker 'Z,' wrote the fourth in a series of attacks on the "Cockney School of Poetry" (Bate 366). He described the poetic "mania" that was taking hold of "farm-servants" and “superannuated governesses," and that was afflicting poor, uneducated Keats (519). He finds himself amused by Keats's attempts to make use of Greek mythology in his poetry, yet finds it only fitting for someone who, after all, "knows Homer only from Chapman" (522). Lockhart suggests, by predicting that "[Keats's] bookseller will not a second time venture $£ 50$ on anything he can write" (524), that Keats's poetic growth should be hindered by his unfamiliarity with the classics. As it happened, Keats's next, and final, publication, Lamia, Isabella, The Eve of St. Agnes and Other Poems (1820), demonstrated his uncommonly fast poetic growth in its maturity and brilliance. Far from hindering his progress, Keats's openness to mediation, and his ability to learn from his mediators, contributed to it. 
The details surrounding the composition of the Chapman's Homer sonnet are well known. First recorded by Charles Cowden Clarke, in his Recollections of Writers, the story has been retold in various biographies, including those of Walter Jackson Bate and Robert Gittings. On an evening in October 1816, Keats and his old school friend Charles Cowden Clarke pored over an edition of Chapman's Homer that had been lent to Clarke. Picking out famous passages, aided by their previous knowledge of Pope's version, they stayed up all night reading to each other. Keats left at daybreak, and by ten o'clock that morning the sonnet was in Clarke's hands. It differed only a little from the final version (Stillinger, Texts 116-17).

Keats's response to Chapman's Homer is not purely intellectual and what he takes out of the encounter far exceeds a basic synopsis of Homer's narrative. As he describes it in the sonnet, he "breathe[s]" the "pure serene" of Homer (7), and the images of discovery and wonder in the final sestet suggest an intensely profound experience, leaving him speechless, “[s]ilent” (14) with "wild surmise” (13). The quality of the sonnet comes down to what Charles Rzepka calls an "unmediated transmission" of sublime power (72): Keats's inhaling of the essence of Homer, and the composition of the sonnet that results from it. The very nature of translation means that Keats's experience is inescapably mediated, but the phrase "unmediated transmission" conveys the pure sense of sublime - the "pure serene" of line 7 - that Keats takes out of Chapman's translation. In the title of the poem, “On First Looking into Chapman's Homer," Keats not only announces, but celebrates, the fact that he is reading a translation. In embracing his mediated reading he is able to take from a mediated text his own sense of an unmediated Homer.

Chapman was not the only mediator involved in Keats's first looking into the translation; Clarke, who had an early influence on Keats's reading, also played a 
significant mediating role. When Keats met Clarke at Enfield school, of which Clarke's father was headmaster, Clarke introduced Keats to, among other writers, Spenser (Clarke 125), the first of the great poets Keats "devoured," as Clarke describes his reading (Rollins 2: 148). In Keats’s September 1816 epistle, “To Charles Cowden Clarke," written a few months before the Chapman's Homer sonnet, he traces somewhat timidly Clarke's influence on him, both personal and literary, thanking him for his "kindness," without which, he wonders, "what might I have been?" (73). He speaks of Clarke's "classic ear" (24), and here we can see why Keats felt he was getting at the real essence of Homer when he read with Clarke. For although Keats was open to mediation, he was still selective in his mediators. Clarke's "classic ear" suggests a keen familiarity with, or sympathy for, classical poets such as Homer. Reynolds, who shared a deep friendship with Keats, was a writer himself (Gittings 140-41). Benjamin Bailey worked exhaustively at his studies, and as Robert Gittings writes, "his heavily annotated Paradise Lost served as a model for Keats's later methods of reading" (227). In Keats's Reading of the Romantic Poets Beth Lau describes Keats's circle of friends as one that "helped stimulate and focus his reading and thinking about poetry" (6). Many of Keats's readings of Shakespeare are informed by the criticism of William Hazlitt, whom Keats greatly admired, whereas other critics of his beloved Shakespeare, such as Johnson and Steevens, became the enemy of Keats's cross-marking pen (Jackson, Romantic Readers 190-91). Keats trusted that Clarke, like Chapman, understood the sublime power of Homer, and, reading with Keats in a social setting, would be able to impart this knowledge.

The epistle continues, reminding Clarke, "[t]hat you first taught me all the sweets of song" (53). Keats was a student of sorts for his entire career, and he looked 
to both the poets he read first-hand and friends who could mediate his reading experience for guidance and influence. He puts himself in the position of a student of Shakespeare by using the phrase "humbly assay" (7) to describe his reading in "On Sitting Down to Read King Lear Once Again.” Much later, in a letter of May 1819, Keats would tell Sarah Jeffrey that he must always live a "fevrous life along with Poetry" because "I cannot resolve to give up my Studies" (2: 113). At the beginning of his poetic career, however, it was Clarke, his literary friend and guide, to whom Keats's poetic gratitude was directed.

Clarke's account of the pair exploring the text together illustrates a social event of sorts (129-31). In the sonnet itself Keats speaks of "hear[ing] Chapman speak out loud and bold" (8), and it is almost certain that he heard Clarke do the same as they "read aloud some of the famous passages" (Bate 85). Keats's first look into Chapman's Homer was a shared experience with Clarke, and his inclusion of this social aspect in the sonnet reveals how vital Clarke's mediating presence was to Keats's own reading experience. The sonnet itself ends on a note of sociability, for Cortez is not alone as he surveys the Pacific, but alongside "all his men" (12) who “[1] ook'd at each other with a wild surmise" (13), a social interaction of their own. Similarly, Clarke describes “the reward of one of [Keats's] delighted stares" (130) after the reading of a particular passage. Clarke mediated the reading experience for Keats in two ways: he read aloud to, and with, Keats, and he directed Keats's reading to specific passages. "One scene I could not fail to introduce to him" (130), he writes.

The three poems written directly after the Chapman's Homer sonnet continue to celebrate the social reading experience. In “Keen, fitful gusts are whisp' ring here and there," the speaker describes being "brimfull of the friendliness / That in a little cottage I have found" (9-10), and in the following lines connects this friendliness to 
reading Milton and Petrarch (11-14). "On Leaving Some Friends at an Early Hour" focuses on writing rather than reading, and instead of being "brimfull of the friendliness" he finds his "spirit" at such a "height" (13) he is moved to "write down a line of glorious tone, / And full of many wonders of the spheres" (11-12). Bate describes the sonnet as the result of "the elation" Keats felt "in at last being warmly welcomed by a group of people who liked poetry" (94); in other words, a group of readers.

Leigh Hunt is one of the friends referred to in the title of "On Leaving Some Friends," and the "little cottage" in which Keats finds such "friendliness" in "Keen, fitful gusts" belonged to him (Bate 93). Nicholas Roe make it clear in his book, John Keats and the Culture of Dissent, that Hunt was also a champion of sociability. Roe cites Hunt's comments about Wordsworth in the notes to The Feast of the Poets, in which he "recommended 'a better acquaintance with society' [for Wordsworth]," (117) because he "lives too much apart, and is subject ... to ... solitary morbidities" (qtd. in Roe 117). The importance Keats places on sociability and friendship helps him to avoid the "solitary morbidities" that a poetic life can bring.

In the poem "To My Brothers" he describes what appears to be a deliberate attempt to prevent poetic isolation. The sonnet was written on Tom Keats's birthday, 18 November 1816 , and presents a scene of content, quiet sociability. While the poet attempts to compose "rhymes" (5), his brothers read, and their "eyes are fix'd, as in poetic sleep, / Upon the lore so voluble and deep" (6-7). He is set slightly apart, writing while his brothers read, but the emphasis is on companionship; he is not alone. The scene depicted in this sonnet differs a great deal from the one painted by Clarke in his recollection of reading Chapman's Homer with Keats. The story of the first reading of Chapman's Homer describes the joyful excitement of two friends 
reading aloud to each other, whereas "To My Brothers" is characterized by silent tranquillity as

Small, busy flames play through the fresh laid coals, And their faint cracklings o'er our silence creep

Like whispers of the household gods... (1-3)

Reading and writing in silent companionship like this is, to Keats, one of "this world's true joys" (13). It is no wonder, then, that Keats encouraged George to read with him from across an ocean. After George had sailed to America, Keats contrived to have them read together by suggesting they read Shakespeare at the same time:

I shall read a passage of Shakespeare every Sunday at ten o Clock - you read one [a]t the same time and we shall be as near each other as blind bodies can be in the same room. (Letters 2: 5)

In Keats and Embarrassment, Christopher Ricks writes of Keats's letter that "Keats sets such store by the attempt to imagine a writer or a reader because doing so will release reading and writing from the inevitable anxieties of solitude" (195-96). According to Ronald A. Sharp, friendship was "fundamental" to Keats, and in his reading and poetic lives, it was no less so (68).

The connection between reading and friendship for Keats cannot be overstated. In his article on the subject, Sharp asserts that "friendship stands at the center of Keats's conception of poetry" (69). To support his point, he a quotes a passage from "Sleep and Poetry," in which Keats writes that "the great end / Of Poesy [is] that it should be a friend / To sooth the cares, and lift the thoughts of man" (245-47). The interweaving roles of both friendship and poetry to alleviate suffering is vital. Theodore B. Leinwand writes about Keats "self-medicat[ing] with an early draught of Shakespeare" (110), which, though it is a nice image, does not address the 
complexities involved in Keats's treatment of his reading as a sympathetic friend. For Keats, Sharp notes, "tragic poetry eases the heart more than pastoral poetry," and this is "presumably because it is based on a more comprehensive view of life" (70). In the "vale of Soul-making" letter of April 1819, Keats writes about the necessity of "a World of Pains and troubles ... to school an Intelligence and make it a soul" (2: 102). Great tragic poetry combines the articulation of suffering with the emotional reassurance that makes it an ideal sympathetic friend; it has "a soul." Ricks notes that "the simply pleasurable is never a prospect for [Keats]" (Embarrassment 161). Not only this, but he also "comes to a truer sense of [the relationship between the pleasurable and unpleasant] when he makes reading and writing themselves part of the complex of feelings" (161). To illustrate his point he quotes a passage from the epistle to Charles Cowden Clarke, in which Keats evokes "Miltonian storms, and more, Miltonian tenderness" (58). Ricks does not focus on friendship here, but it is certainly interesting that in a poem very much about his literary friendship with Clarke, Keats uses his reading of other poetry to articulate his gratitude. Sharp notes with admiration "Keats's ability to accept the sorrow inherent in friendship without reducing friendship to therapy" (80), and this is the case with his reading, too. Rather than simply "self-medicate" by reading, he is consoled by the beauties that sorrow affords the text.

The notion that friendship can be derived from art stayed with Keats, and in "Ode on a Grecian Urn" he concludes that the urn itself is a "friend to man" (48). For Keats, looking at art and reading poetry could have the same effect as a good friendship; a great poem is a friend and the shared experience of a great poem is an act of friendship. In a chapter called "Socializing with Books" in Romantic Readers, H. J. Jackson illuminates a common theme among Romantics as the "[identification] 
of books with human companions" (122). Even when practised alone, reading can be an act of friendship, but in the Romantic period, and within Keats's circle, it was often supplemented by communication about the reading experience.

Keats's circle was literary and their conversations about literature extended from talks, to letters, to notes in the books themselves. Books that were circulated among his friends were marked, had notes written in them, passages underlined in approval, or crosses placed next to disagreeable passages. These marks and marginalia mediate the text, drawing attention to passages which may have been overlooked by another reader. Jackson points out that writing marginal notes in other people's books was not only common, but encouraged (Romantic Readers 183). She also notes that for Keats, more than other annotators, textual notes and markings had a "personal application" (188). He would use his books as a springboard for conversation with his friends. The conversation between Clarke and Keats that this book-sharing produced is exemplified exquisitely by a comment of Keats's next to a passage in Clarke's Chaucer: "Is not this perfectly beautiful dear Charles?" (qtd. in Jackson 183).

Keats often wrote marginal notes intended for other readers. Jackson finds that many of his Milton notes "were written of the sake of other readers, to communicate Keats's enthusiasm" (Romantic Readers 194, original emphasis). "Several" of these notes, she continues, are written in the first person plural as though including others, and the set of notes at the beginning of the first volume ... serve the customary purpose of introducing the work by outlining the nature of Milton's genius - something Keats had little reason to spell out for himself. (194) 
His sociability in reading is carried through in his marginal notes, but these annotations also allow him to take his role as a social reader further by becoming a guide for those who will encounter his notes in their own reading. He gave his copy of Milton to Mrs. Dilke, and the inscription addressed to her shows that "the notes are not just a reader's private memoranda but a guide prepared for a friend" (Jackson, Marginalia 224). His notes for Mrs. Dilke would have been a gift as well as a guide. "For Keats," writes Sharp, "gift giving, in its widest metaphorical sense, was the quintessential act of friendship" (78). For someone who placed constant emphasis on the connection between his reading and his friendships, marginal notes and underlinings are fitting gifts. "Friendship for Keats," Sharp continues, “was ... conducted in the spirit of gift exchange" (78), and an exchange of ideas was the gift that Keats most commonly asked of his friends; to Reynolds he once wrote, "Whenever you write say a Word or two on some Passage in Shakespeare" (Letters 1: 133). The text itself is an ideal site for this sort of exchange because of the proximity that the annotator's ideas maintain to the text itself, allowing for a more direct mediation of another's reading. Keats's gift to Fanny Brawne of one of his copies of Shakespeare was complete with notes for her, and lovingly mediated her reading of the text. Through writing marginal notes, Keats became a mediator himself.

In Beth Lau's discussion of marginalia in Keats's Paradise Lost, she concedes that there is a degree of "humbleness" involved when underlining a text, but draws attention to the "inherently subversive qualities" of the practice by citing Jackson, Lipking and Christensen, who report similar findings (19). Although marginalia are often viewed as a conversation between author and reader, Jackson is careful to point out that they are, in fact, "not always friendly and not usually the product of a meeting of equals" (Marginalia 82). The pen is a powerful tool for the reader as well 
as the writer, and even though Keats's own markings were generally affirmative, especially in the texts of authors he loved, the act of producing marginalia at all would have been empowering. Jackson asserts that by combining "the functions of reading and writing" in annotation, the reader was afforded "considerable power" (Marginalia 90).

While Jackson points out that the tensions created by the power of the reader can suggest a rivalry between reader and author (90), in Keats's marginalia this is not necessarily the case. Lau argues that Keats's marginalia demonstrate a "sense of comfort and intimacy" with the host text (21). This intimacy with the text logically leads to a sense of solidarity with its author. In an October 1818 letter to George and Georgiana Keats, Keats displays this intimacy by writing, "I think I shall be among the English Poets after my death" (Letters 1: 394). Ricks asserts that "[w]hat Keats most valued in the English poets ... was a sense of brotherhood with his peers" ("Keats's Sources" 154), and it is this sense of brotherhood, of equality, that Keats affirms when he talks about being "among" them. The term "brotherhood" is useful, for it illustrates Keats's open and quietly confident attitude to his reading of the great poets and consequent writing of his own poetry, while being distinct from the sense of friendship that characterizes his mediated reading. Lau lists nine original poems that Keats copied, and in some cases even drafted, into his books, making his own work part of "the volumes of work by ... great writers of the past" such as Shakespeare and Milton, and effectively anthologizing himself alongside them (Paradise Lost 20).

It is Keats's sense of brotherhood that gave him what Jackson calls an “intense sympathetic engagement with the author" (Romantic Readers 193). His sympathies with the author are not limited to poets, either, for Jackson also points out 
that "he picked out statements he could endorse" in Hazlitt's criticism (Romantic Readers 188). Lau draws attention to the way Keats viewed the authors he admired as benevolent guides; Shakespeare is his famous "presidor," and in "Specimen of an Induction to a Poem" he imagines Spenser looking down at him "encouragingly" (Paradise Lost 21).

Keats is always aware of the author as he reads. Goellnicht points out that although Keats believed that each reader could, and should, "bring their own subjective ideas and emotions, their own identity," to what they read, he also "insists that the response of each reader is grounded in certain textual fixities, certainties" ("Keats on Reading" 199-200). He respects the existence of the text itself, and nowhere is this more literally true than in the books he annotates. "The essential and defining character of the marginal note throughout its history," writes Jackson, "is that it is a responsive kind of writing permanently anchored to preexisting written words" (Marginalia 81).

Even in his negative marginal notes, Keats demonstrates a strong sense of his poetic peerage. In defending criticism against Shakespeare, for example, he marks his disagreement not with his own words, but with lines from Shakespeare's plays, sometimes slightly modified to suit his purposes (Jackson, Romantic Readers 191). In other books, he records his approval by comparing passages to the work of other authors he admires. Jackson points out, for example, that in his notes on Burton's Anatomy of Melancholy Keats links Burton's text with those of authors such as Sterne, Shakespeare, Milton, Jonson, and Massinger (Romantic Readers 189). Not forgetting the friends who would also read the book, he wrote some personal notes to Charles Brown, too, humorously including "a little list of the bald men Keats knew, which begins with Brown" (Jackson, Romantic Readers 189). The interest in these 
notes for Jackson is that they may be "a revelation of the way Keats's mind worked while he was reading, one text instantly recalling another stored in memory" (189). She is quick to point out that "it was not a particularly unusual procedure to take note of parallel working and parallel ideas" (189), but in the case of Keats, it is useful to see that he did this, for it gives us a practical indication that Keats's mind really was "teeming," as he writes in "When I have fears," with all that he had read (2). Until his "teeming brain" finds release in his own poetry, he releases and reorganizes, creating new relationships for the reading knowledge he has stored in his mind.

Keats's associative reading has another implication, too. In the first chapter I discussed Keats's letter to Bailey in which he talks about the immensity of what "has gone through the human intelligence" (1: 209) in terms of retention and re-reading. 'Going through' also suggests a transformative process, however, which is connected to the way in which Keats associates different works as he reads, and lends itself to his creativity. Gittings suggests that because Keats "shared a profound experience with Clarke" as they read Chapman's Homer together, "a great deal of his past reading at school fused with his immediate reading that night" (130-31). The readings he had stored in his mind, given the appropriate associative stimulation (i.e. Clarke's presence), emerge as allusions or sources for the images in the poem; however, these images are not simply borrowed, they are transformed. In his paper on "How many bards gild the lapses of time," Robert F. Gleckner writes of a "clear Spenserian allusion [which] is both subsumed in, and transformed by, Keats's recollection of passages from Paradise Lost" (19). Keats's readings of both Spenser and Milton mediate and inform each other in order to contribute to Keats's imagery. Gittings writes that "Keats was always stimulated by a striking quotation" (258), which is related to both his penchant for association and his openness to mediation. 
Quotations are mediated by their displacement from their original setting, and offer a ready association between the original and the work that references them.

When Jackson calls marginalia "psychological preparation for the reader" she is talking about a copy of Keats's Poems (1817) that Richard Woodhouse annotated after Keats's death, in which he includes various quotations by Keats and others at the beginning of the book (Marginalia 25-26). Woodhouse was preparing potential readers for an initiation into Keats's poetry, but marginalia prepare readers in a number of ways. For Keats, marginal notes and textual markings were often a means of preparation for writing. Jackson writes that he "marked a Shakespeare as he studied the plays with a view to improving his own writing" (Romantic Readers 253), and reading in general was an ongoing stimulus for his creativity.

Keats also used marginalia in preparation for his reading. Jackson identifies one of the consequences of marginal and textual markings as that they "guarantee attention on further reading" (Romantic Readers 187). When Keats marked or underlined passages in books that were not intended for friends, he would have been establishing at least part of the focus of his subsequent readings, initiating a conversation between a past and present self, whether consciously or not. In the case of King Lear, however, we know that he made a conscious effort to prepare for his re-reading. Although the King Lear sonnet is not part of Keats's marginalia in the strictest sense, for it is not a direct response to the text, and was not written directly into the book, it is worth discussing in relation to his marginalia nonetheless, for he deliberately copied it into his Folio edition of Shakespeare, opposite the title page of the play itself (Stillinger, Texts 160, Spurgeon 50-51). What the significance of this was for Keats, we cannot know, but it is appropriate that his reading in preparation for writing should begin with a sonnet, a creative enterprise of his own. 
Conversational marginalia illustrate the prominence of books as sites for sociability and friendship, especially in a literary crowd such as Keats's circle. Gillian Russell and Clara Tuite note that the study of sociability in the Romantic period has largely focused on this literary type by quoting Paul Magnuson's comment that the "public space of Romanticism is the book and the periodical" (4). In Romantic Sociability, however, they set out to remind us of the various other sites for sociability in the period: "the theatre, the debating club, the bookshop or the dining room" (4). It is the first of these that I will discuss here, for the theatre was something that Keats, as Bate writes, "delighted in" (236).

Theatregoing in the Romantic period was a thoroughly social experience. Julie A. Carlson notes that even after the spectators' shared experience of viewing the play itself had ended, theatregoers were left with at least one common interest, as well as a topic of conversation (156). William Hazlitt in particular, Carlson finds, "comes to ascribe sociability to the operations of theatres through his captivation by the theatricality of new philosophical friends" (148), and would also find "actors ... the most reliable friends" (160). One theatregoing experience could play host to numerous modes of friendship. In the case of a Shakespeare play, spectators who were also readers might share a sense of the text of the play as a friend (as we have seen in certain marginalia), and by extension, the author as a friend or brother. To the most fervent admirers of Shakespeare, even his characters could hold the place of "a person's oldest and dearest friends," writes Carlson (158). Yet with the fusion of so many different types of friendships, the theatre was also a place where these friendships could collide, for they were not always mutually compatible.

Carlson describes Hazlitt's aversion to seeing representations of beloved characters on stage because "seeing them embodied by others destroys the sanctity of 
one's 'own conception' of them" (158). She quotes Hazlitt on the actor Edmund Kean's Othello, saying that although Othello is Kean's "best character, and the highest effort of genius on the stage ... we wish it was better than it is" for it "disturbs our idea of the character" (qtd. in Carlson 158). In other words, Kean's representation "disturbs" Hazlitt's reading of the character of Othello. The mediation of the character through Kean's acting is an invasive experience for Hazlitt, whose unyielding opinion had been set before he saw the play.

Keats's celebration of mediators, on the other hand, extended to the stage. He had a particular admiration for Kean, whom he reviewed in December 1817's “On Edmund Kean as a Shakespearian Actor." "There is an indescribable gusto in his voice," he marvels, "by which we feel that the utterer is thinking of the past and future, while speaking of the present" (230). Keats uses Hazlitt's own word, "gusto," a quality Hazlitt finds in the works of Shakespeare, but not necessarily in performances of his plays. In this particular case at least, Keats finds them in both. Hazlitt writes that although Kean "is in general all passion, all energy," he lacks "imagination, that faculty which contemplates events, and broods over feelings with a certain calmness and grandeur" (5: 271). These remarks are based on a single performance, but in the sixteen reviews of Kean's acting in Hazlitt's A View of the English Stage, there is a basic pattern of genuine admiration for Kean's abilities, somewhat tarnished by a recognition that his portrayals are never going to display "perfect acting" (5: 208); indeed, he concedes, neither will those of "any one else" (5: 208). His 1814 review of Kean's Richard sums up his thoughts on Kean’s “manner of acting" as "a perpetual assumption of his part, always brilliant and successful, almost always true and natural, but yet always a distinct effort in every new situation, 
so that the actor does not seem entirely to forget himself, or to be indentified with the character" (5: 184).

The qualities Kean lacks, as Hazlitt singles them out, share a remarkable similarity with what Keats called the "poetical Character" (Letters 1: 386), or “camelion Poet" (1:387), which "has no character - it enjoys light and shade; it lives in gusto, be it foul or fair, high or low, rich or poor, mean or elevated - It has as much delight in conceiving an Iago as an Imogen" (1:387). Keats connects Kean's performance to poetry explicitly when he writes that it excites the same "pleasures" in him as a "melodious passage in poetry" ("On Edmund Kean as a Shakespearian Actor" 229). These "pleasures" are both "sensual" and "spiritual" (229). The addition of a "spiritual" element is what gives Kean's performance its gusto, and Keats is able to see it because he responds at a fundamental level to Kean's voice: when Kean performs, Keats writes in his review, "his tongue must seem to have robbed 'the Hybla bees, and left them honeyless"' (229-30). He explains the spiritual element he finds in Kean's voice by comparing it to poetry itself. "The spiritual is felt," he writes, "when the very letters and points of charactered language show like the hieroglyphics of beauty" (229). He continues, saying that when "the spiritual portion of those lines to which Kean adds a sensual grandeur" is heard, it seems, particularly to "one learned in Shakespearian hieroglyphics," to be "spring[ing] warm from the lips of Kean" (229). His use of the word "hieroglyphics" to describe both the physical text and his experience of hearing Kean's voice read the same words, suggests that in hearing Kean, he is able, on some level, to visualize Shakespeare's words themselves. Voice is one of the primary resonances for Keats in his mediated reading: he celebrates Chapman's voice in the Chapman's Homer sonnet (in which he also visualizes the listening experience); he and Clarke read Chapman aloud 
together; he speaks of the "luxury" of having Reynolds read aloud passages of Homer to him. His emotional response to the gusto of Kean's voice therefore suggests the suitability of Kean as a mediator of Shakespeare. As Jonathan Mulrooney puts it, Kean acts as "a translator of [Shakespeare's] codes into the 'sensuous life' of spoken verse" (240).

Theatrical mediation did not provoke the same creative response in Keats as his other mediated reading, which resulted in poems such as the Chapman's Homer sonnet and "Keen, fitful gusts," but it may well have aided his reading. In the cases of both the performances of Kean and Keats's book-reading, Keats responds to the aural experience he finds in them; he responds to voice. In her discussion of reading aloud in Reading, Writing and Romanticism, Lucy Newlyn highlights the eighteenthcentury theorist Hugh Blair's "distinction between voice as the vehicle of sympathy and the printed word as its empty signifier" (345). Blair is referring to public oration, such as lectures, and not poetry or theatre, but the notion of the voice having a particular sympathetic expression is certainly apt here. Sympathy is to be expected from friends, and it is not surprising that Keats should respond to any sort of reading aloud, whether theatrical or not, when it exhibits this feature of friendship. Newlyn discusses Coleridge's idea that "the capacity of words to convey emotion lies in their musicality" (358). The connection between music and poetry cannot be overlooked, and it is made throughout Keats's poetry. In "On Leaving Some Friends," for example, Keats finds music an inspiration for writing poetry:

The while let music wander round my ears, And as it reaches each delicious ending, Let me write down a line of glorious tone, (9-11) 
In his review, Keats speaks of Kean's voice in terms of his "music of elocution" (229), and Hazlitt believed, as he wrote in his essay “On Milton's Versification," that the aural was more immediately accessible in Milton's work than the "picturesque" was "because the language of music blends more immediately with, and forms a more natural accompaniment to, the variable and indefinite association of the ideas conveyed by words" (4: 38).

To experience the thrill of being read aloud to was common in the Romantic period. Jackson contends that the Romantic prevalence of reading aloud "cannot be too often stressed," and notes that conversations in social circles "were often prompted by reading aloud" (Romantic Readers 54). In his "Detached Thoughts on Books and Reading," Charles Lamb describes Milton and Shakespeare as "two poets you cannot avoid reading aloud" (175), suggesting that poetry that lends itself to being read aloud is of a higher order. "Books of quick interest," Lamb continues, "that hurry on for incidents, are for the eye to glide over only. It will not do to read them out" (175).

I liken Keats's response to voice in theatre to his enjoyment and appreciation of hearing poetry read aloud to him by his friends, but even with their similarities, the two situations are markedly different. The public space of the theatre cannot rival the much more intimate setting of a pair or small group of friends reading aloud together, yet it is not simply a matter of private versus public. This binary does not account for dramatic texts, which can be read as a performance in the theatre, at home with friends, or even aloud on one's own, as Lamb's essay demonstrates. In Reading Public Romanticism Paul Magnuson defines what is public as anything that is published (7), and many of the books Keats and his circle read to each other would have been 'public' by this definition. Some of these books would have had audiences 
far larger than that of a single theatre performance; when so many texts are public, then, the difference in the reading experience is in the setting, and social atmosphere, in which these books were consumed.

In Romantic Readers, Jackson emphasizes the common ground created by reading aloud in pairs, rather than less intimate larger groups (56). Lamb also preferred to read in pairs: "More than one," he writes, "and it degenerates into an audience" (175). Keats himself wrote sonnets inspired by literary gatherings with friends ("Keen, fitful gusts" and "On Leaving Some Friends") but neither of these display the immense creative power of the Chapman's Homer sonnet, written after the experience of reading aloud as a pair. Reading a published book gives a reader a sense that he or she is part of a greater audience of fellow readers, but the physical presence of only one to a few other readers stimulates the mind and carries with it the potential for immense imaginative power. Although Lamb indulged in and celebrated the theatre's virtues of sociability, like Hazlitt, he preferred reading to seeing Shakespeare (Carlson 146). Lau accounts for this preference in Keats's Paradise Lost, writing that in the view of Lamb and Hazlitt, while "the abstract quality of words stimulates the mind" the theatrical experience "render[s] the viewer's mind passive" (51). I have already mentioned Keats's ability to visualize the words of Shakespeare as he watched a play. This may allow him to take out of a performance the same abstractness that written words do for Lamb and Hazlitt, and then apply it to, or associate it with, his next reading. As with his other mediated reading, what Keats responds to in theatre is voice. The aural experience of reading stimulates his mind, and is inextricably linked to mediation. 
"Loud and Bold": Keats Reading through Mist

The aural experience is vital to Keats's celebration of mediated reading, and part of its appeal for Keats is that he finds "mistiness" within it (Letters 1: 274). I began the previous chapter with a discussion of Keats's April 1818 letter to John Hamilton Reynolds, in which Keats writes about the "luxury" of the thought of being read to by his friend (1:274). I draw attention to the letter again, in order to focus, this time, on mistiness. In the letter, Keats imagines Reynolds reading Homer aloud to him and decides that the experience would "be, from its mistiness, perhaps a greater luxury than reading the thing one's self" (1: 274). Keats does not define "mistiness" here, but it is clear that it is not simply Reynolds's reading aloud that produces "luxury"; it is the mistiness that arises from the aural experience of hearing Reynolds read aloud that makes the experience significant.

Keats's use of the term "mistiness" has not been explored extensively in scholarship, but a few critics have addressed it. Martin Aske takes it as the cloudy portent of Keats's “anxiety of influence." This "anxiety of influence," he says, "arises from the fact that antiquity is signified by the absence of a material text which the poet can make his own" (4, original emphasis). He does not argue, or dwell on, this point; he simply takes for granted the damaging effect of "anxiety of influence," and moves on. It is in order to make the text "manageable," he continues later on, that Keats "desires to mediate or even to displace his relation to antiquity through other voices, other texts, as though a naked encounter were too painful and importunate" (34). He suggests that Keats's preference for a mediated version of Homer stems from a desire to avoid the original, but this is not necessarily the case. The title of the sonnet "On First Looking into Chapman's Homer," for example, not 
only acknowledges but also announces that Keats is reading a translated text. He embraces the fact of its mediation, as he celebrates his new familiarity with his poetic predecessor. In the letter to Reynolds, his preference for a mediated version of Homer is signified by its being "a greater luxury," a phrase which indicates a positive desire for an aural experience of Homer, rather than the avoidance Aske suggests.

Jonathon Shears is also interested in mist. He restricts his focus to Keats's narrative poetry, although he also makes a point of discussing "his poetic philosophy - especially through the well-known 'Negative Capability' and the 'burden of the Mystery'” (159). Shears's narrow poetic focus serves the opening statement of his Keats chapter, that Keats "pushes formal misreading to its logical extreme" (159), but does not take into account a larger consideration of Keats's reading. Even though the chapter purports to be about how Keats reads Paradise Lost, it is largely focused on Keats's failure to complete his own epic. Shears does not refer to the "mistiness" letter, which is integral to my own affirmative interpretation of Keatsian mist, in his discussion, although he makes use of other letters Keats wrote to Reynolds at around the same time. In engaging with Shears's argument, I intend to show that Keats's reading, particularly of Paradise Lost, illustrates a positive relationship with mediating mist. Keats's broader use of the term mist does not reflect his sense of failure, but his willingness to be "content with half knowledge" (Letters 1: 194). It is partly Shears's assumption, not explicitly stated, of Keats's "anxiety of influence" that leads him to the conclusion that Keatsian mist must be equated with failure. Shears claims not to be "of a Bloomian persuasion" (178), yet his argument appears at the very least to be derived from the "anxiety of influence" model. His insistence on Keats "reading against the grain" of Milton (171, 173-74 and 176-77) 
bears a striking resemblance to the misreading and correction that is central to Harold Bloom's argument for "anxiety of influence." That is,

Poetic Influence ... always proceeds by a misreading of the proper poet, an act of creative correction that is actually and necessarily a misinterpretation. The history of fruitful poetic influence ... is a history of anxiety and self-saving caricature, of distortion, of perverse, wilful revisionism. (30)

The connection between Shears's argument and Bloom's becomes even clearer when Shears describes Keats's "reading against the grain” as "misreading” (159).

As Jack Stillinger points out in a note to "How many bards gild the lapses of time," "even relatively early in his career, Keats's 'anxiety of influence' was well under control" (Complete Poems 423), and most recent criticism has followed suit by moving away from the theory. Beth Lau, in her 1998 book, Keats's Paradise Lost, contends that "if the Romantic poets were oppressed by the burden of the past and anxiety of influence, they were not crippled by it" (21). In 2001, Christopher Ricks took this even further, saying that Keats "declines the invitation to figure in the dark melodrama of Harold Bloom's Anxiety of Influence. How unmisgivingly Keats speaks of influence, especially while happily under it" ("Keats's Sources” 154).

Despite all this, the shadow of "anxiety of influence" looms; Shears's book, published in 2009, is evidence of this, and his interpretation of Keats's mist suffers from it. By taking Keatsian mistiness away from the grip of anxiety theories, I will examine it as an affirmative indication of Keats's desire for mediation. I do not set out to displace Bloom's theory - as Lucy Newlyn points out, straightforwardly "antiBloomian replies" ignore the same concerns with poetic influence that the anxiety theory itself does (Paradise Lost 14) - but to suggest that in the case of Keats, his 
openness and receptivity in reading suggest a positive relationship with poetic influence.

Aske's 1985 book, Keats and Hellenism, was written before the critical shift away from the theory, but his brief discussion of mistiness is useful, for even in assuming "anxiety of influence," he recognizes Keats's "desire to mediate ... his relation to antiquity through other voices, other texts" (34). Aske takes this desire for mediation to be a symptom of "anxiety of influence" and of the concurrent need to make texts "manageable." Yet, if we look at Keats's mistiness without "anxiety of influence," it is possible to distinguish between Aske's more defensive manageability and a more receptive Keatsian accessibility.

Keats's freedom from "anxiety of influence" may usefully be read in the context of his sociability and the importance he places on friendships that mediate his reading. This sociability, and the appreciation of mediated texts that comes with it, presupposes Keats's openness to the ideas of others. Ronald A. Sharp writes that Keats never "despair[ed] of human imperfection," but instead, "grapple[d] with its implications" (77). Similarly, his recognition that he was not able to read Homer in the original Greek allows him to "grapple," to explore the mist, through reading.

Shears, however, views mist, in Keats's narrative poetry at least, as "associated with his failure as an epic poet" (177), and he supports this with a passage from the first canto of The Fall of Hyperion, in which the speaker shouts out Apollo's "misty pestilence" (1.205) which haunts "all mock lyricists, large self worshippers, / And careless Hectorers in proud bad verse" (1.207-8). Shears is right in identifying Keats's "misty pestilence” here as signalling a certain anxiety about his failure to produce epic poetry. However, Keats uses "misty" with a different meaning to when he refers to "mistiness" in reading Homer or being "in a Mist" 
(Letters 1: 281). Keats uses the word "mist" and its variants, "mists," and "misty," frequently throughout his poetry. As a point of comparison, Shakespeare uses the word and its variants sixteen times (Concordance of Shakespeare's Complete Works), Milton does twelve times (Bradshaw), and Keats a full thirty times (An Electronic Concordance to Keats's Poetry). A third of Keats's uses come from Endymion alone, but it was a word he continued to use as his poetry matured, most famously, perhaps, in the first line of "To Autumn," in which autumn is described as a "[s]eason of mists" (1). The $O E D$ cites six different meanings for "mist" ("mist, $n .{ }^{1}$," "mist, $n .{ }^{2}$ "), and in Keats's poetry, I find at least three distinct meanings. The first is the strictly literal, meteorological sense of mist, which he uses most often in Endymion; second, a signifier of things mystical, supernatural or of the gods; and the third use describes a state of, or place in, the human mind or imagination. Shears writes in terms of this third meaning, but Apollo's "misty pestilence" in fact falls under the second meaning. The "pestilence" is "misty" because it is of Apollo, and Apollo is a god: mystical, divine.

Mist was something that resonated with Keats in others' poetry, too. It is a word that surfaces regularly in the works of Shakespeare and Milton, as I have shown, and Keats's marginal notes and markings to Milton's Paradise Lost suggest that Milton's use of the word was particularly influential to Keats's thinking. Keats had been reading Milton at around the time the "mistiness" letter was composed (Letters 1: 274), and this letter, I suggest, is the first instance in which Keats, influenced by Milton, refers to mist using the third meaning I referred to: that of a state of, or place in, the human mind or imagination.

Beth Lau notes that "Keats marks several passages in [Paradise Lost] in which mist is mentioned," as well as "two passages that describe light veiled by a 
cloud" (Paradise Lost 192). Milton opens the third book of Paradise Lost by referring to his own physical blindness and the blindness to divine matters that all humans face. He then invokes God's “celestial light" (3.51), asking that it

Shine inward, and the mind through all her powers

Irradiate, there plant eyes, all mist from thence

Purge and disperse, that I may see and tell

Of things invisible to mortal sight. (3.52-55)

For Milton, metaphorical mist veils divine understanding from his own mortal knowledge, in much the same way that Keats's inability to understand Greek acts as a mist which obscures the original Homer from him. The major difference is that Milton requires divine assistance to see through the mist, whereas for Keats, there is no need to break through the mist; the mistiness on its own is enough.

Another use of the word "mist" in Paradise Lost is perhaps a more accurate guide to Keats's appreciation of it:

his [Satan's] form had yet not lost

All her original brightness, nor appeared

Less than archangel ruin'd, and excess

Of glory obscured: as when the sun new risen

Looks through the horizontal misty air

Shorn of his beams, (1.591-96)

The simile of the sun's muted beams illustrates not only the "brightness" that remains in Satan's fallen form, but also the beauty of it. The "misty air" holds, and, in a way, stabilizes, that original brilliance. The lines may well have resonated with Keats, who felt that mistiness would not take away anything essential from the 
original Homer in a mediated reading experience. They certainly struck Keats, for he underlined them in his own copy of Paradise Lost (Lau, Paradise Lost 84).

Also underscored in that copy are the following lines from Book V:

Ye Mists and Exhalations, that now rise

From hill or steaming lake, dusky or grey,

Till the sun paint your fleecy skirts with gold, (5.185-87)

In the lines following these, we learn that the mists and exhalations are rising "[i]n honour to the world's great author ... Rising or falling still advance his praise" (5.188, 5.191). Once again, Keats is struck by the image of the sun mingling with the mist, but here the mist also has a divine connection. God, the "great author," is hailed by mist, and thereby also signified by mist. Keats chooses to hail Homer, a "great author" himself, and of godlike status among poets, through mist.

In the Chapman's Homer sonnet, Keats describes his reading as an inhalation of poetic power. The $O E D$ connects the word exhalation with mistiness, defining it as "[t]hat which is exhaled; a mist, vapour, etc." ("exhalation"). If we equate Milton's uses of "exhalation" with "mist," then mist, an exhalation of the earth, exists for the very purpose of being inhaled. Keats takes mistiness out of mediated reading experiences, and mistiness in a mediated text allows Keats to reach the "pure serene" and "breathe [in]" the essence of it. Keats often refers to reading in terms of eating, as more than one critic has noted. Christopher Ricks explores this in Keats and Embarrassment (180), and Stuart Sperry describes eating and drinking in Keats as "the common prelude to imaginative experience" (52). "I long to feast upon old Homer" Keats tells Reynolds in the "mistiness" letter. In the King Lear sonnet he "consume[s]" (13) "[t]he bitter-sweet of this Shakespearian fruit" (8). In the Chapman's Homer sonnet, however, Keats neither consumes nor reads; he "breathe[s] 
the pure serene." The inhalation of the pure essence of Homer replaces the "consuming" of unmediated texts, and it is perhaps this sort of experience Keats has in mind when he talks about "mistiness" to Reynolds. Being unable to encounter Homer first-hand, he is unable to "feast upon old Homer" as he does upon Shakespeare, but the "mistiness" of hearing Homer read aloud allows him to experience that "pure serene" again by breathing it in.

In a sonnet composed in August 1818, four months after the "mistiness" letter, Keats explores mist again, inspired by his "[v]aprous" (4) surroundings at the top of Ben Nevis. The sonnet follows:

Read me a lesson, Muse, and speak it loud Upon the top of Nevis, blind in mist!

I look into the chasms, and a shroud Vaprous doth hide them; just so much I wist

Mankind do know of hell: I look o'erhead, And there is sullen mist; even so much

Mankind can tell of heaven: mist is spread Before the earth beneath me; even such,

Even so vague is man's sight of himself. Here are the craggy stones beneath my feet;

Thus much I know, that, a poor witless elf, I tread on them; that all my eye doth meet

Is mist and crag - not only on this height,

But in the world of thought and mental might. (1-14) Mist pervades the entire poem. In a letter to his brother Tom, Keats, describing his expedition to the top of Ben Nevis, writes that "there came on a Mist, so that from 
that part to the very top we walked in a Mist" (1:353). The literal mist which envelops Keats in the moment of composition metamorphosizes into that mortal mist clouding human vision of not only the divine, but "man's sight of himself" (9). Yet, though the mist is smothering one sense, sight, it also opens up another, hearing. When the speaker invokes the Muse in the opening lines, it is not only because, "blind in mist," he cannot see, and must hear her instead, but also because the mist surrounding him facilitates the invocation by amplifying the poet's sense of hearing. It is the amplification of hearing that appeals to Keats when he talks of "mistiness" to Reynolds, and in that letter, as in "Read me a lesson, Muse," the amplified sense of hearing is in direct relation to having something read aloud to him. In the sonnet, Keats purposefully asks the Muse to "[r]ead [him] a lesson" out loud. His response to blindness is to call for help through an aural experience of poetry. He places the muse herself, inspirer of poets, in the role of a mediator, reading what is hidden from the poet. Although the mist hides divine sight from him, it simultaneously amplifies a mediated reading of divine knowledge.

Mist acts as a stimulus for active reading. Shears recognizes this, and applies it to Byron and Shelley's readings of Milton. In the case of Keats, however, he finds that mist hinders, rather than stimulates, imaginative exploration. Discussing the Milton passage I quoted earlier, in which the sun's light shines through mist, he writes that "both Byron and Shelley" are "stimulated" in their readings by the "majesty of Satan's unfallen state" (177). Keats, on the other hand, who comments elsewhere that Milton's use of the word "vale" is "a beautiful thing made more beautiful by being reflected and put in a Mist" (qtd. in Shears 177), only focuses on the mist itself. For Byron and Shelley, Shears argues, mist "stimulates the active 
mind to search into Satan's origins and complete the image" (177). He does not believe this is the case with Keats, writing:

The Miltonic mist displays the Magnitude of Contrast that prompts the imagination, the light and shade. ... [I]t involves a definite sense of progression, and more particularly the acknowledgement of the process of time in the narrative, the one factor that Negative Capability must deny. (177) Earlier, Shears writes that Keats's negative capability "is on the one hand an ambiguity that activates the mind and on the other an ambiguity that disengages it" (167). He chooses to focus on the latter, arguing against "the notion that Keats's 'Mysteries' [always] promote imaginative vigour" (167). On the following page, he makes a distinction between "receptive ... as opposed to creative ... Negative Capability" (168). Keatsian receptivity, however, engenders a response, and this is often a creative one. In the first chapter I indicated that negative capability is something Keats requires in a poet, but not in a reader. Donald C. Goellnicht talks about a reader being able to "appreciate a state of Negative Capability in which he or she can accept perplexities with half-knowledge" ("Keats on Reading" 205), making a subtle distinction between the poet who employs negative capability and the reader who appreciates it. Yet, I have also argued that for Keats, reading and writing are part of the same process, and looking at negative capability in terms of Keats's reading is useful for that reason.

That negative capability rejects the "irritable reaching after fact \& reason" (Letters 1: 193) is perhaps what suggests to Shears that Keats is not stimulated by Milton's image to the degree that Byron and Shelley are. Walter Jackson Bate notes a tendency in criticism towards stressing "fact and reason" in Keats's comment, when, he contends, "the significant word ... is "irritable"" (249). Keats does reach into the 
mist, and he does so without irritability. He does not oppose "fact and reason" in themselves, but he does not reach in order to find them; exploring is the end in itself. Stuart Sperry writes that "Keats's chief contention is that poetry exists in 'half knowledge,' in uncertainty and mystery, and that an element of the problematic or probational ... is not only justifiable but vitally necessary to its effects" (62). One of these "effects" is that it affords an imaginative response from the reader. Lau discusses one of Keats's marginal notes to Paradise Lost, in which he wonders, “[w] hat creates the intense pleasure of not knowing?" and concludes that it is a “sense of independence, of power from the fancy's creating a world of its own by the sense of probabilities" (qtd. in Lau, Paradise Lost 49). For Keats, Lau explains, "uncertainty or indefiniteness in poetry is appealing" precisely because "it activates and empowers the reader's imagination to complete what the text only sketchily provides" (49). If Miltonian mist causes Byron and Shelley to search within, around, and through it to "complete the image," as Shears writes, mirroring Lau's own phrasing, then Keats, "content with half knowledge" (Letters 1: 194), is receptive to what is in the mist. Perhaps he does not come to a "final conclusion" (Sperry 63), but his exploration of the misty image produces, as Sperry writes in his discussion of negative capability, "a deeper awareness of the "Penetralium of mystery"” (63).

In an 1817 letter to Benjamin Robert Haydon, Keats writes that "with a great poet the sense of Beauty overcomes every other consideration, or rather obliterates all consideration" (1: 194). Yet the obscurity that excites his senses also leads to imaginative “consideration.” Lau separates Keats's appreciation of obscurity from his "emphasis on pictorialism and vivid sensory impressions," also found in his Paradise Lost annotations (52). Keatsian mist, however, sometimes brings these 
apparently contradictory things, appreciation of both the obscure and illustrative, together through imaginative process.

In "Read me a lesson, Muse," the mistiness surrounding the speaker amplifies his aural experience by veiling his sight. The insistence that his muse "speak it loud" in the poem recalls the earlier Chapman's Homer sonnet, in which Keats hears Chapman "speak out loud and bold" (8). In that sonnet, hearing Chapman speak is a springboard for Keats's other senses: "Then felt I like some watcher of the skies" (9). The synaesthetic shift from sound to sight mirrors the experience, as William Hazlitt describes it, of viewing a painting with "gusto," which "is where the impression made on one sense excites by affinity those of another" (4: 78). Paul McNally has commented on not only Keats's use of synaesthesia, but also the inadequacy of the term itself, which is defined in the $O E D$ as " $[\mathrm{t}]$ he transfer of the meaning of a word from one kind of sensory experience to another" ("synaesthesia"), to describe Keats's complex associations of sense and imagination (530). He quotes Bate, who writes that Keats's “imagery ... is less concerned with replacing one sense with another than it is with substantiating one sense by another, to give further dimension and depth" (McNally 530). Keats's sensory rhetoric does not only substantiate other senses, it also invokes imaginative stimulation.

His reading inspires creative thought through his senses, and, as in "Ode to a Nightingale," it is often the lack of visual perception that begins the process. Lau points out that Keats celebrates the physical blindness of Homer and Milton as something that excites their creative imaginations. She writes that "blindness is an asset to a poet in that it fosters cultivation of mental conceptions over actual, visual perception" (Paradise Lost 49). Mist obscures some senses, while it overwhelms others, and these spur not only other sensations, but the working of the imagination. 
In Kean's performance of Shakespeare, Keats singles out his voice, purposefully narrowing his sense impressions in order to amplify it. Hazlitt takes issue with the fact that in viewing a theatrical performance, "so much is done by the senses, that the imagination is not prepared to eke out any deficiency that may occur" (qtd. in Lau, Paradise Lost 52). In contrast, part of Keats's appreciation of the theatre lies in his ability to let his senses act as a doorway to his imaginative faculties. Keats is able to shroud his other senses in mist, so that Kean's voice is amplified, and from there, his mind opens.

This is partly because Keatsian mist is ultimately a function of his poetic mind. Mist obscures a reader's senses, but not the essence of the poetry that is seen or heard. Earlier, I defined Keatsian mist as a state of, or place in, the human mind. The spatial dimension of mist is suggested by the reader's ability to explore within it. Shears, appropriately, calls mist "one of Keats's favourite poetic places" (177). Aske also alludes to the spatial dimension of mist by speaking of Keats's "displacement" from antiquity through mist, highlighted by Keats's inability to read Greek and therefore the original Homer (34). Mist, for Aske, as a signifier of Keats's displacement, acts as a barrier between him and the works he reads. I suggest, however, that mist, in its spatial capacity, serves as a meeting place for Keats and the authors, times and places he is displaced from. That is not to say that Keats never felt this displacement, for there is a keen awareness of it in some of his letters. In a September 1818 letter to his brother George, for example, he compares his writing to Byron's, saying, almost cheekily but assertively, “[Lord Byron] describes what he sees - I describe what I imagine - Mine is the hardest task" (Letters 2: 200). Similarly, through mediated reading, he can only read what he imagines. Yet he celebrates this mediated reading when he describes its "mistiness" to Reynolds. As a 
site in the human mind, mist accommodates his imagined, or mediated, reading. The mistiness that Keats inhales is necessitated by mediation, and is often the result of a social experience of reading. Julie A. Carlson writes that for Hazlitt, the "theatre is a house ... of ... recollection, which we enter when we wish to recollect our oldest friends" (160). If the theatre is a meeting place for Hazlitt and old friends, mist is a meeting place for Keats and his poetic predecessors.

The idea of mist as a meeting place also hearkens back to the importance of sympathy in Keats's reading, and the sense of brotherhood he feels towards his poetic peers. A meeting suggests a sympathetic relationship between equals, and in the letter to Reynolds, "mistiness" is connected to both aural and social experiences. In her discussion of reading aloud in Reading, Writing and Romanticism, Newlyn highlights the sympathetic aspect of voice versus text, including Hugh Blair's idea that "voice [was] the vehicle of sympathy and the printed word ... its empty signifier" (345). He is talking about oration rather than poetry, but it is not hard to believe that Keats, who readily found sympathy in poetry, describing it as "a friend / To sooth the cares" in "Sleep and Poetry" (246-47), may have found an even greater degree of sympathy in poetry read aloud. This poetic sympathy is, ideally, mutual. Newlyn cites Hazlitt's essay "On the Difference between Writing and Speaking," in which he highlights the sympathy of the audience rather than the speaker: "The orator sees his subject in the eager looks of his auditors; and feels doubly conscious, doubly impressed with it in the glow of their sympathy; the author can only look for encouragement in a blank piece of paper" (qtd. in Newlyn, Reading, Writing and Romanticism 333).

In the misty, mediated reading experience, Keats finds his own thoughts and feelings reflected, or understood, through the sympathetic voice of his mediators. In 
his marginal notes to Paradise Lost, Keats describes Milton's use of vales in Heaven and Hell as "a sort of delphic Abstraction a beautiful thing made more beautiful by being reflected and put in a Mist" (Lau 77). The image of beauty reflected recalls the first of Keats's poetic axioms in the famous February 1818 letter to John Taylor. He writes: "I think Poetry should surprise by a fine excess and not by Singularity - it should strike the Reader as a wording of his own highest thoughts, and appear almost a Remembrance" (Letters 1: 238). That great poetry should appear to reflect a reader's own thoughts, and that a great poet's "beautiful thing" can be reflected in mist, highlights the importance of mist as a meeting place, where the opacity of the mist blends the thoughts of the readers' and poets' minds. William Hazlitt writes of Shakespeare that his mind has the "power of communication with all other minds" (5: 47), which suggests a similar meeting of minds to that which takes place in mist. Keats also alludes to this sort of communication in the 1818 poem, "Bards of passion and of mirth." Addressing the great bards, who have "left [their] souls on earth" (2), he writes that while their heavenly souls "commune / With the spheres of sun and moon" (5-6), their "earth-born souls still speak / To mortals" (29-30), teaching and guiding them in a meeting of minds.

Keats's use of the term "Remembrance" to describe the reading experience is equally significant, for it elevates the reader to the level of the great poet's mind. Remembrance features in The Fall of Hyperion, through the character of Moneta. Shears questions Keats's choice of using Moneta as a muse in the poem, writing that " $[\mathrm{t}]$ here is a curious masochism in the fact that Keats chooses Moneta or memory, when he desires to escape the influence of Milton, and the pressures of Miltonic narrative" (176). I suggest that Keats's use of Moneta as a muse signals not his anxiety, but his confidence; it is an attempt, at the very least, to take part in that 
brotherhood of great poets and an assertion of memory as part of a larger poetic consciousness. An explicit connection between forgetting and mist is made only once in Keats's poetry. In "I cry your mercy - pity - love! aye, love," a lovesick speaker considers that he may "[f]orget, in the mist of idle misery, / Life's purposes" (12-13). The "mist of idle misery" is not the mist of mediation, which allows thoughts that are like a remembrance, but the connection between this mist and forgetting highlights the connection between mist and the mind, and, more specifically, between mist and memory. The apparently contradictory effects of mist are due to the varying states of the readers' or speakers' minds. In an active mind, mist enables remembrance; the meeting place in mist is the result of a reader's willing it into being, as in "Read me a lesson, Muse." In "I cry your mercy" the speaker exists in "idle misery," indicating a wilful passivity of action. He forgets because he cannot actively call upon a mediator such as the Muse, and loses his "ambition blind" (14). There is also a subtle connection made between mist and memory in "Ode to a Nightingale." The speaker begins with a desire to "[f]ade far away, dissolve, and quite forget / ... / The weariness, the fever, and the fret" (21-23) of human life and suffering. The action of dissolving, connected here to forgetting, is reminiscent of the opacity of mist, suggesting once again the connection between mist and memory. After the speaker's mind has worked actively throughout the poem, however, the speaker is brought back to himself and realizes that he cannot forget, after all. If one allows it, mist can cause forgetting, but it can also be a stimulating space for the mind to work in, especially if the mind actively seeks it out and engages with it.

"Nightingale" highlights the aural experience of listening to the Nightingale's song, and can be usefully compared to "On First Looking into Chapman's Homer," in which Keats celebrates the aural experience of reading. In the Chapman's Homer 
sonnet, Keats likens his experience of hearing Chapman's translation read aloud to that of a "watcher of the skies / When a new planet swims into his ken" (9-10). The image of the planet swimming into vision suggests a fluidity in the aural experience of poetry - although it is described in terms of a visual simile. The fluidity in the early sonnet is picked up once more in "Nightingale," in which the poet hears the Nightingale's very soul "pouring forth" (57) through its song. This time the fluid image of "pouring forth" illustrates an aural, rather than visual, experience. Although "Nightingale" is not literally about reading, the connections made between poetry and the song of the Nightingale in the poem make it significant to a discussion of Keats's reading. The Nightingale sings in a "melodious plot / Of beechen green" (89), the double meaning of the word "plot" heightened by the reader's knowledge that now, the Nightingale only sings as a character in Keats's own plot, the ode itself. In the fourth stanza, the poet cries out to the Nightingale that he "will fly to thee" (31) "on the viewless wings of Poesy" (33). Whether he reaches the Nightingale through reading poetry or writing is not immediately clear, and it may point to a larger experience of poetry, which includes both. What is apparent in the poem, however, is that in the space inhabited by both the Nightingale and the poet's mind, reading stimulates the creative imagination and spurs his writing. Furthermore, as Jack Stillinger points out, the subjects of all the odes, including the Nightingale, are, in a sense, "text[s]" that the speaker "become[s] reader of" (Reading "The Eve of St. Agnes” 87). I therefore explore the speaker's listening in this poem in terms of reading.

The primary difference between the emphases on the aural experience of reading in the Chapman's Homer sonnet and "Nightingale" is the focus on "hear[ing]" Chapman in the early sonnet, and "listen[ing]" to the Nightingale in the 
ode. While hearing Chapman's voice is a result of Keats's deliberate opening up to poetic power, the more active listening involves the reader/listener in the creative process itself through its association with the imagination. By the very act of listening in "Nightingale" Keats hears its song as well, but the focus of the poem is the mental process that the poet's listening provokes. Hearing Chapman is almost serendipitous for Keats; though he had "travell'd in the realms of gold" (1), he had not sought out either Homer or Chapman. He was not, in fact, even listening for Chapman's voice, but rather, as the title of the sonnet says, "[1]ooking." Hearing in "Nightingale," on the other hand, is part of a larger meditation caused by his listening, and the use of the verb "hear" in the poem is passive: "The voice I hear this passing night was heard / In ancient days" (63-64). Having already discovered the power of poetic voice in reading Chapman's Homer, he now seeks it out, and, by listening, he actively invites hearing it. In the Chapman's Homer sonnet the act of hearing itself is emphasized ("I heard Chapman" (8)), but in "Nightingale" the emphasis is on the voice, and the act of hearing comes second to it.

The shared experience of hearing a poetic voice is conveyed in the sonnet through Cortez's men, and is paralleled in "Nightingale" by the speaker's awareness of a connection with the past: readers of the "ancient days" (64) have heard the Nightingale's music too. If we consider the shared experience of hearing Chapman's Homer as equivalent to seeing a performance of Shakespeare, or reading aloud with a friend, listening to the Nightingale mimics the experience of reading to oneself. In both cases there is a larger audience, but in "Nightingale" the recognition of the past is not a social experience. As the song of the Nightingale stimulates the poetic imagination, the speaker, alone and listening, turns the focus of the poem inward, and by the end of the fourth stanza the poem is situated within the poet-speaker's mind. 
Without seeing the Nightingale, the speaker pictures her singing "[i]n some melodious plot" (8), and when he tells her to fly "[a]way!" (31) he manages almost effortlessly to reach her: "Already with thee!" (35). He reaches the Nightingale instantaneously, which suggests that this meeting place, like mist, is in the poet's mind. Although it exists in the mind, where "there is no light" (38), it is given a physical presence by the terms it is described in: the night is "tender" (35) and the darkness "embalmed" (43).

The mind as a physical space in "Nightingale" carries some similarities to the "untrodden region of [the speaker's] mind" (51) in "Ode to Psyche." "Psyche" ends with the speaker building a shrine for his muse

In some untrodden region of my mind,

Where branched thoughts, new grown with pleasant pain, Instead of pines shall murmur in the wind: (51-53) In two of his earlier poems, "On Sitting Down to Read King Lear Once Again" and “Spenser, a jealous honourer of thine," Keats had likened literature to forests, and in his letters he had likened reading to wandering (1.170). In the first stanza of "Psyche" the speaker "wander[s] in a forest thoughtlessly" (7), and the assimilation of the two metaphors for reading here seems to parallel an early reading process. After the speaker's sighting of Psyche, his thoughts become "branched" (52), like the branches of the forest trees themselves. Psyche, muse-like, has stimulated the poetspeaker's mind. The speaker also offers himself up to be Psyche's "choir" (44), "voice," "lute," and "pipe" (46), and the connection to music, particularly with the inclusion of "voice," suggests an awakening of the speaker's poetic voice. The poem is saturated in images that reflect his thoughts on reading and the imaginative process. In the third stanza, the speaker offers to be Psyche's "voice, thy lute, thy pipe, thy 
incense sweet / From swinged censer teeming" (46-47). The "censer teeming" inside his mind recalls the "teeming brain" of "When I have fears" (2). Instead of teeming with the collected knowledge from his reading, however, his mind teems with incense, ready to excite others' senses. Like poetic genius, it mingles in the atmosphere, to be inhaled by readers.

As the speaker listens to the Nightingale's song in "Ode to a Nightingale" he turns his thoughts inward, and in doing so he reaches the Nightingale, who sings in a "melodious plot / Of beechen green, and shadows numberless" (8-9). The "plot" is an enclosed space, yet the "shadows numberless" within it suggest that what it contains - the Nightingale's song, and the speaker's thoughts - are limitless. Likewise, in "Psyche," the location of the speaker's mind suggests a boundary for Psyche's temple, while the "branched thoughts," "wild-ridged mountains" (55) and "wide quietness" (58) within the "working brain" (60) appear to be boundless. Keats's comment to Bailey, that "perhaps more goes through the human intelligence in 12 days than ever was written," is worth recalling here for it also suggests the boundlessness of the human mind (Letters 1: 209).

Like the mists at the top of Ben Nevis, darkness in "Nightingale" obscures the speaker's vision but amplifies his aural sense, and enables him to actively listen, opening up, in the process, his imaginative faculties. The speaker describes the "soft incense" that "hangs upon the boughs" (42), recalling the "incense" in his shrine to Psyche, and indicating that his imagination is at work alongside his senses. He does not smell, but must "guess each sweet" (43). It is significant that one of the $O E D$ definitions of the verb "read" is "to guess" a meaning which, though obsolete by Keats's time, is last cited as being used in 1590 by Spenser, whom Keats read and 
admired ("read, v."). Although the speaker cannot see, he can read his surroundings by guessing.

The cognitive process that listening provokes has been at work throughout the entire poem, gaining momentum until it reaches its imaginative height through guessing in the fifth stanza. It is not until the sixth stanza, however, that the term "listen" is actually introduced, through the striking Miltonic phrase, "[d]arkling I listen" (51). The word "darkling" reminds us that listening is a result of the poet's loss of visual perception, which has heightened both his sense of hearing and imaginative capabilities. The phrase is central to the poem, at line 51 of 80 , and stands out, separated from both the line before it by a stanza break, and the words following it by a semi-colon. Susan Wolfson points to the importance of “interstanzaic space," which marks a turning point, or "pivot," between the stanzas separating the "dialogues of the mind with itself" (314). The phrase "[d]arkling I listen" answers the "murmurous haunt of flies on summer eves" (50) that ends the fifth stanza. The fifth stanza is the most illustrative in the poem of the speaker's working imagination, and the idea that these lines are in dialogue with each other indicates the importance of listening to that imaginative breadth.

"Darkling I listen" is also directly followed by the speaker's musing on "easeful Death" (52), and the realization at the end of the stanza that in death the speaker would "have ears in vain- / To thy high requiem become a sod" (59-60). Unable to hear, he would also lose the imaginative capability that listening provokes. In the third stanza the speaker expresses his desire to "forget" (21) the "weariness, the fever, and the fret" (23) of the world, "[w]here but to think is to be full of sorrow" (27). On one level, the mind, confronted with the physical world of suffering, is only a vehicle for "sorrow." Thinking gives way to the imagination, however, and 
by the fifth stanza, Keats's thoughts are creative rather than sorrowful as they establish his surroundings, "guess[ing] each sweet." If thinking is equated with suffering, a reminder of death and illness, then in the deeper imaginative state brought on by the Nightingale's song and Keats's own sense of oblivion, suffering is obliterated. Even death is not associated with suffering, but is rather "easeful" (52), one to whom the poet can call "soft names" (53), and who can take the poet's "quiet breath" (54) "with no pain" (56). As tempting as this vision of death is, however, its totality makes it ultimately undesirable, for while it obliterates suffering, it also obliterates the imaginative power that the speaker has carefully cultivated throughout the poem. The speaker must, and does, snap out of his dreamlike state to conclude the poem, realizing that in death he would "become a sod" (60). His senses have guided and engaged his imagination, and as a "sod," he would lose these senses entirely. He articulates this in the recognition that in death he would be unable to listen to the Nightingale's song: "Still wouldst thou sing, and I have ears in vain" (59). He would also lose the vital connection of the senses to imaginative power, which, at the end of the poem, he transforms into poetic voice. 
Questioning, Silence, and Creative Stimulation in Keats's Poetry of 1819

The image of death taking away the poet's "quiet breath" in the sixth stanza of "Ode to a Nightingale" suggests a loss of the poet's ability to write, and recalls the early 1818 sonnet, "When I have fears that I may cease to be," in which Keats expresses a fear of dying before the thoughts and ideas in his "teeming brain" have been articulated into poetry (2). In "Nightingale," however, it is the realization of the senselessness of death that propels him out of his dream: "Still wouldst thou sing, and I have ears in vain" (59). Where "When I have fears" focuses on the loss of the ability to write, the speaker of "Nightingale," unable to hear, is concerned with the inability to read the Nightingale's song. That an exploration of the inner workings of the creative mind leads up to this point suggests the importance that reading has on Keats's creative process.

The speaker of "Nightingale" is brought back from the imaginative realm to reality with the realization that "the fancy cannot cheat so well / As she is fam'd to do" (73-74), and that the oblivion he craved is neither feasible nor desirable. He cannot remain in an imaginative state that ignores the realities of human suffering. The imaginative stimulation that is produced by this temporary state of oblivion continues, however, as the speaker asks the ode's concluding questions: "Was it a vision, or a waking dream? / Fled is that music: - Do I wake or sleep?" (79-80). The Nightingale's song has faded until it is "buried deep / In the next valley-glades" (7778), and the only sound that breaks the silence is the speaker's own voice.

Throughout the poem, the speaker has read the music of the Nightingale, by hearing and listening, and his surroundings and mind through guessing. The questioning that now appears is the next step in that progression of reading, and, like guessing, it 
carries a creative momentum that hearing and listening do not reach. Questioning as a creative form of reading can become in itself a composition, or at least a creative impetus, and nowhere is this more pronounced than in "Ode on a Grecian Urn," which I will discuss later in this chapter.

The silence that accompanies the Nightingale's disappearance marks a significant change in the speaker's imaginative activity. Until this point, silence had been the domain of the actively listening speaker, and the Nightingale's ongoing song was not only a backdrop and springboard to the speaker's mind and thoughts, it also played an active role in the speaker's articulation of his meditative mood. The introduction of "listening" in the sixth stanza marks a refocusing of the poetspeaker's mind from a contemplation of his surroundings to a mode of self-reflection, and this turn inwards makes his silence all the more apparent. The tensions between the silence of the speaker and the sound of the Nightingale's song are at their highest in this stanza, as the speaker imagines the Nightingale continuing its song in “ecstasy" (58) while death has taken his "quiet breath" (54) from him. The speaker's entering the interrogative mode at the end of the poem demonstrates an awareness of the necessity of these tensions for creativity, for when the tension is released by the disappearance of the Nightingale's song, the speaker's questioning voice reinstates the balance of sound and silence with his own non-silence.

The emergent questioning voice is hinted at throughout the poem. Silent, active listening led to the speaker "guessing" his surroundings in the fifth stanza. If an act of guessing is to "form an opinion or hypothesis" ("guess, v."), an act of questioning takes that hypothesis further, and explores the possibilities it raises. In stanza 5, the speaker "guess[es] each sweet" around him (43), and in the final lines of the poem, he progresses from guessing the state of his surroundings to questioning 
his own state of conscious awareness, as he asks, "[d]o I wake or sleep?" (80). His imaginative state has incorporated the silence which enables his mental facilities to perform. Where the Nightingale's music spurred his initial creativity in guessing, it is clear by the colon in the final line, "Fled is that music: - Do I wake or sleep?" that the silence prompts the questioning. There is a strong connection between poetic silence and imagination, and questioning acts as a bridge between them. Leon Waldoff opens his book, Keats and the Silent Work of the Imagination, with a discussion of a letter Keats wrote to Benjamin Bailey on 22 November, 1817 (1). In the letter, Keats talks about "the simple imaginative Mind" which "may have its rewards in the repeti[ti]on of its own silent Working coming continually on the spirit with a fine suddenness" (1: 185). Not only is his description of the imagination working silently particularly apt here, but his phrasing also shares some remarkable similarities with the dramatized working of the imagination in "Nightingale." Throughout the ode the imagination works silently as the speaker listens to the Nightingale's song, and then with a "suddenness" marked by the speaker's being tolled back to himself, his awareness changes, and he gives voice to the imaginative creativity that had been developing only silently up until that point.

The imaginative stimulation of "Nightingale" occurs in a state of silence, and is given voice in Keats's poetry by the interrogative mode. Susan Wolfson asserts not only that Keats "took pleasure in arguing, often from a deliberately contrary stance, to test prejudices, pursue new ideas, widen speculation" (187), but also that "[a]ll the major metaphors and critical insights for which Keats is famous ... emerge in debates" (189). "[M]ost of these debates," she continues, "are provoked by a question" (189). The examples of these debates that she offers, such as the development of Keats's theories about negative capability and the "Mansion of Many 
Apartments," all come from the Letters (189-90), indicating the importance of questioning not only to Keats's poetry but to his thinking in general. Wolfson points out that Keats questions rather than theorizes "as a method of critical investigation" (186-87). Questioning as a mode of philosophical, or even poetical, enquiry presupposes not only an audience, but a dialogue with that audience, and in the case of Keats, is characteristically open and receptive. It is also a powerful vehicle for his creative imagination, and it is appropriate that, especially in his later poetry, he uses questions to fill poetic silence.

Silence prompts the questioning that opens "La Belle Dame Sans Merci," which Keats composed in April 1819, perhaps only weeks before "Ode to a Nightingale" and "Ode on a Grecian Urn." An unnamed speaker asks "O what can ail thee, knight at arms, / Alone and palely loitering?" (1-2), followed by the observation that " $[\mathrm{t}]$ he sedge has wither'd from the lake, / And no birds sing" (3-4). There is some ambiguity as to who speaks those last lines. According to Wolfson they could either be a "potentially meaningful reply to the questioner or a further effort by the questioner to provoke a reply from the knight" (297, original emphasis). My reading takes up the second of Wolfson's suggestions: the questioner's observations not only demonstrate further explorative inquiry on his part, they also create a context for his asking the question in the first place. Wolfson further observes that the addition of these lines "extends the mood of inquiry by stressing the incongruity of figure and place" (297). I would extend this even further to say that the speaker asks his initial question because "[t]he sedge has wither'd from the lake, / And no birds sing," and these details make the knight's presence even more mysterious. The last three singlesyllable words of the short last line of the stanza ("And no birds sing") are given equal emphasis by the poem's metre, so that the silence it describes resounds eerily 
once the line is completed. This emphasis on the silence of the knight's surroundings further suggests that, as in "Nightingale," the silence itself prompts the questioner to speak.

The second stanza follows the same pattern as the first. The questioner asks the knight what ails him, and elaborates on his enquiry by a subsequent observation:

O what can ail thee, knight at arms,

So haggard and so woe-begone?

The squirrel's granary is full,

And the harvest's done. (5-8)

By the third stanza, the speaker's questioning has been replaced by an account of his observations:

I see a lily on thy brow

With anguish moist and fever dew,

And on thy cheeks a fading rose

Fast withereth too. (9-12)

These observations are a reading of the knight's sickly state. The speaker's reading has taken him from an examination of the landscape in the first two stanzas, to a reading of the knight's suffering in the third, where he notes the knight's "anguish," "fever," and fading colour. This narrowed focus on the knight's symptoms transforms into an attempt to articulate a possible answer to his own questions, and his reading begins to take on a creative aspect, which, when the knight finally speaks in the fourth stanza, is shown to be what Wolfson calls "latent narrative" (298). The knight's story "confirms all [the] intuitions and imaginative surmises" (298) that the questioner intimated in his reading of the scene in the first three stanzas. 
When the knight finally begins to speak in stanza four, the questioner's creative part is done, and he becomes a silent audience for the knight's deadly tale. The knight may be influenced by the questioner's surmises, which perhaps explains how well his tale "confirms" what the questioner has already guessed. Yet it could also be that the presence of an external, questioning voice has given the knight the necessary jolt to take him out of his trance. Unlike the questioner, however, the knight has no creative role in the poem; all he can do is recite his version of past events.

The knight's reading of his own tale bears some striking similarities to "Nightingale." The first is the "light"-footed lady (15), who becomes a "light-winged Dryad" in "Nightingale" (7). We also learn that not only does the belle dame sing, like the Nightingale does, but in hearing her sing, the knight becomes oblivious to all else:

I set her on my pacing steed, And nothing else saw all day long, For sidelong would she bend, and sing A fairy's song. (21-24)

The knight's sense of hearing is amplified by his selective vision, as he sees only the lady, and he constantly notes the sounds she makes: she "made sweet moan" (20); "in language strange she said - / I love thee true" (27-28); she "sigh'd full sore" (30). His senses of smell and taste are also heightened, as he recognizes "roots of relish sweet / And honey wild, and manna dew" (25-26), anticipating the "Nightingale" speaker's "guess[ing] each sweet" in the darkness (43). The real significance of these similarities however, is that they underscore the differences with which the knight and the poet-speaker of "Nightingale" read their subjects and surroundings. The 
knight and poet-speaker fill different literary roles to begin with; the knight is a lover who wants to woo the beautiful lady, whereas the speaker of "Nightingale" is chiefly a poet, who exercises his creative powers in listening to the Nightingale's song. These differences not only explain why the two figures produce such different readings for their surroundings, but highlight just how important active listening is to a poet's reading.

I have already discussed the difference between hearing and listening in a previous chapter. Where the poet-speaker listens to the song of the Nightingale and internalizes his thoughts in the darkness, the knight hears the song of the belle dame, and, although he is blind to everything but her, has a solely external focus. The poetspeaker wishes for death, then returns to himself, alive with creative power; the knight is released from his "thrall" (40), but only into imminent death. At the end of "Nightingale," the poet-speaker breaks his silence with a question, but questioning has come too late for the knight, who ends his tale with a repetition, "And no birds sing" (48), and relapses into silence, most likely never to return. By reading the song of the Nightingale through active, silent listening, the poet-speaker awakens his poetic powers. The unhappy knight, who, "in struggle with questionable shapes of interpretation" (Wolfson 299), fails to read his situation correctly, is rewarded only by the ability to read the full version of his tale before he dies. The knight's selective hearing (as opposed to listening, which is both attentive and comprehensive) allows for an interpretation of his situation that is in line with his desire for the lady, but is not the 'true story.' His hearing lacks the reciprocity that characterizes the poetspeaker's listening, and allows for creative stimulus. Only his audience, the questioner of the first three stanzas, can take creative advantage of the silence the 
knight leaves behind him. The knight's silence is the product of his inability to read and/or create his own narrative.

Attached to listening is a sort of sympathetic reciprocity, which opens a dialogue, a meeting, in the mind between the Nightingale and the speaker, and so the silence of the poet-speaker is filled with latent poetic power. The creative process of the poet-speaker does not begin with the silence of the Nightingale's ended song, but is spurred by the Nightingale's music, and begins to take shape in the speaker's silence of listening. With his senses amplified in the darkness, the speaker begins to create by guessing, recalling an 1818 sonnet in which Homer is described as having "triple sight in blindness keen" ("To Homer" 12). The idea of a "keen" "blindness" suggests the same amplification of non-visual senses that the speaker of "Nightingale" experiences, and the connection of the poet-speaker with one of Keats's poetic predecessors suggests the great potential for further creative ability. The speaker of "Nightingale" has, after all, been creating all along, and even the silence he endeavours to fill is not created by the Nightingale's distance; the speaker's own creative imagination brings him back to himself. "Forlorn!" he says, "the very word is like a bell / To toll me back from thee to my sole self!" (71-72). "Forlorn" is also the word he has deliberately chosen to describe the "faery lands" (70) he has read into the Nightingale's song. Although his poetic introspection began with his reading of the music, it is he himself who creates the final silence by ceasing his listening, as the word "forlorn" is a product of his own thoughts. This sets the poet-speaker apart from the knight of "La Belle Dame Sans Merci." He not only has a superior capacity for reading, he is also able to create the narrative he reads in the process. 
The creative questioning that emerges at the end of "Nightingale" continues in "Ode on a Grecian Urn." Although the composition order of the odes is unknown, "Grecian Urn" is most commonly placed directly after "Nightingale," and the progression of the speakers' questioning in the two poems also supports this. The questioning in "Grecian Urn" begins in the first stanza, as the speaker, addressing the urn, wonders

What leaf-fring'd legend haunts about thy shape

Of deities or mortals, or of both,

In Tempe of the dales of Arcady? (5-7)

The speaker's first question is immediately followed by six more, all directly concerning the nature and meaning of the subjects and events depicted on the urn:

What men or gods are these? What maidens loth?

What mad pursuit? What struggle to escape?

What pipes and timbrels? What wild ecstasy? (8-10)

The speaker reads the images on the urn by asking questions about them, which evoke what the speaker sees on the urn, and mediate the images for the poem's readers.

In the two following stanzas, the speaker continues to address the urn, but he asks no questions. Instead, he evokes the images on the urn by demonstrating an affinity with, and understanding of, the images, as if he has already answered his own questions about them. The speaker's ability to answer his own questions is hinted at in the title of the poem: it is an ode "on" and not "to" the urn. The speaker relies only on his own imagination, his own reactions to the work of art, to give him answers, and so, by the second stanza, he is able to interact with the images on the urn. He injects the urn's images with his own narrative by encouraging the "soft 
pipes" to "play on" (12), and consoling the "[f]air youth" (15) who cannot kiss his love by assuring him, "forever wilt thou love" (20). Jack Stillinger observes that Keats "understood the importance of the individual reader's creativity in the reading process" (Reading "The Eve of St. Agnes" 87), and cites Keats's assertion in the "axioms" letter to John Taylor that "Poetry...should strike the Reader as a wording of his own highest thoughts, and appear almost a Remembrance" (87). He argues that it is the reader's "bring[ing] his or her individual thoughts and recollections to bear on the reading process" (87) that makes this remembrance possible. Keats's theories about readers and reading shed light on what he himself was like as a reader, for even in his greatest poetry, his reading personality is unmistakable. In "Grecian Urn" we see this in his simultaneous mediation and creation in the second and third stanzas. Even at the height of his poetic powers, "he seems," as Stillinger concludes his discussion, "to be positioned on the reader's side outside the works rather than within, sharing the reader's interested view of what is going on in them and wondering, just like the reader, how to deal with the ambiguities they pose" (89).

The speaker's questioning voice is not heard again until the fourth stanza, where it shifts from directly reporting on the images on the urn through questions, to questioning creatively. The first set of questions are similar to the questions of the first stanza, in that they mediate between what the speaker sees on the urn, and what we read in the poem:

Who are these coming to the sacrifice?

To what green altar, $\mathrm{O}$ mysterious priest,

Lead'st thou that heifer lowing at the skies, And all her silken flanks with garlands drest? (31-34) 
The stanza also introduces an entire community to the urn for the first time, and we begin to see that the speaker's creative power progresses simultaneously with the representation of sociability on the urn. His reading in the first stanza is of "men or gods" and "maidens" involved in a "mad pursuit." The individual groups of "men or gods" and "maidens" are emphasized, and the "struggle to escape" pits them against one another. In the second stanza, the speaker begins to insert his own narrative into his reading, creating a part for himself in the scene, which has already moved away from the individual, and concerns of a pair of lovers (alongside a third party, a piper). The sense of community is fully realized in the fourth stanza, in which an entire town proceeds to a sacrifice in "pious" (37) solidarity. At this height of social representation the speaker's creative abilities reach their furthest.

In stanzas 2 and 3, the speaker uses his empathy to creatively attribute feelings to the subjects of the urn. He imagines the grief of the "[f]air youth" at being unable to kiss (18), and calls him "[b]old" (17); the "boughs" (21) and "melodist" (23) are both "happy" $(21,23)$. Now, in the fourth stanza, his questioning voice returns in order to create a world that does not appear on the urn at all:

What little town by river or sea shore,

Or mountain-built with peaceful citadel,

Is emptied of this folk, this pious morn? (35-37)

Through the mingling of narratives in the preceding stanzas, the speaker has interacted not only with the subjects of the urn, but with the original artist too. In articulating this dual narrative, the speaker appoints himself not only mediator to his readers, but also co-artist. He offers us a version of the scene on the urn that does not only highlight what he sees, but also expands upon the original, and in so doing, 
highlights what the speaker imagines, inviting the reader into the mind of this creative spectator.

The poetic power the speaker gains from this work of art can be contrasted with the sense of powerlessness that the speaker of a much earlier sonnet, "On Seeing the Elgin Marbles," suffers on viewing a great work of art. "My spirit is too weak" (1), he feels, and aspiration seems hopeless as he finds that each imagined pinnacle and steep

Of godlike hardship tells me I must die

Like a sick eagle looking at the sky. (3-5)

Five months earlier, reading Chapman's Homer had inspired in Keats a fundamental poetic confidence, but now, viewing the Elgin Marbles, the Keats-identified speaker is overcome by his sense of bleak despondency. Lawrence Lipking compares the two sonnets, noting that the 'effect of such a 'pure serene,' which carries no poison in 'Chapman's Homer,' seems darker" in "Elgin Marbles" (8). Keats gains poetic power from Homer's "pure serene" by breathing it in, by reading it, but he does not read the marbles. The urn, however, is not simply viewed by the speaker, it is read exhaustively, and through this reading, he is able to assert his creative power.

The speaker of "Grecian Urn" deepens his authorial role by depicting what the artist has left off the urn when he introduces the town in the fourth stanza. Though this act is also a creation on the speaker's part, I use the word "depiction" here to highlight the necessary connection between the "little town" and the images already present on the urn; the town could not have been imagined without the image of the townsfolk who have left it. The creation of the imagined town is hesitant at first, as the creative speaker toys with ideas about the town's location: is it near a river, or the sea, or is it even a mountain-village? The hesitance recalls the questions 
of the first stanza, where the speaker wonders if the figures he sees are men or gods. Taking his cue from the image that is visible on the urn - that of a sacrificial procession - he finishes the question with a quiet and subtle confidence: it is a "pious morn" that has "emptied" the town of its people.

The stanza contains its own progression of questioning and creativity. The speaker's initial questions are questions of reading: "Who" (31), he wants to know, are the figures he sees? And where are they going? The next set of questions builds creatively on what is seen on the urn, in order to depict the "little town" that is missing from the urn. By the last three lines of the stanza, the creative imagination is fully at work, and the hesitant creative questions of the preceding lines take shape as the speaker reports on the empty desolation of the town by addressing it directly:

And, little town, thy streets for evermore

Will silent be; and not a soul to tell

Why thou art desolate, can e'er return. (38-40)

The "[a]nd" connecting the lines of enquiry with the address does not answer the questions raised, and the various possibilities (whether the town is by river, sea, or mountain) remain open. As Wolfson points out, however, the "apostrophe ... undoes the very premises of the question" (324). The question has played its role in bringing the town into imaginative existence, and "[w] hat little town" is now irrelevant, even as it remains open to endless possibilities. Questions have become statement, in the ultimate affirmative creation. In "To Ailsa Rock," the questions the speaker asks negate themselves by painting the very image they ask about. Wolfson asserts that as the questions "expand in length and imagination, definite answers come to seem less important than what the very asking of questions produces - an emerging image of dormant power held under a spell" (318). She describes the sonnet as "an apt 
example of Hazlitt's remark that the 'province of the imagination is principally visionary, the unknown and undefined,' because it is this that gives 'birth and scope to the imagination; we can only fancy what we do not know"" (318). Likewise, in "Grecian Urn," once the town takes shape, it does not matter that the questions the speaker initially puts forward remain unanswered.

Waldoff asserts that "[t]he imagination is concerned with what is absent" (7), and in the fourth stanza, at the speaker's creative height, it is what is absent from the urn that engages the speaker's imagination. The speaker no longer requires the questioning that led to the creation of the little town, but he relies on the silence still. The silence involved in the creation of the town, however, is not the speaker's own, but that of the imagined town itself. In a poem full of things "unheard" the little town is the only image to be described, like the urn itself, as "silent." The irony that this silent town is not even depicted on the urn only highlights its integral connection to the urn. Though the speaker creates the little town, he creates it as part of an exhaustive reading of the urn, for in reading into the work of art what is absent, he brings himself closer to a complete understanding of it; closer, perhaps, to its truth (49).

Once again, the imagination performs its "silent Working" (Letters 1: 185). The entire urn is imagined by Keats, but the silent streets of the town are also completely imagined by the speaker - unlike the images that are depicted on the urn, which, though they include "unheard" melodies (11-12) and characters who are eternally unmoving, are also "for ever piping" (24), "unwearied" (23), "panting" (27), and "young" (27), paused in the midst of music and action. David Ferris points out that "urns are not silent, they are ... 'silent forms"” (82). The relationship between silence and the urn in the ode is complicated, for while the urn is clearly related in 
some way to silence, it is never described unequivocally as silent. In the first two lines of the poem it is called a "still unravish'd bride of quietness" and "foster-child of silence and slow time." The urn itself is neither quiet nor silent, but a "bride of" and "foster-child of" it. Both of these phrases indicate passivity on the part of the urn, while also offering us a glimpse into the nature of silence: that the urn is a "bride of" and not "wed to" quietness suggests that quietness has chosen it, and not the other way around; that it is adopted by silence makes its passivity even more apparent. The urn was not, as it were, born silent, but has developed a relationship with silence nonetheless. I have argued already for the strong connection between silence and the creative imagination. The urn, I now suggest, has been adopted by the poet's imagination in order for the poet to complete his exploration of the effect of art on the creative, reading mind.

That the urn is addressed as a "silent form" (44) rather than a silent urn also begs the question of what sort of form the speaker is referring to. Three lines previously the speaker describes the urn as an "Attic shape" and "fair attitude" (41), the latter especially suggesting an artistic representation. This is at once a reminder that the urn is, first and foremost, a work of art, but when paired with the later description of "silent form" it also carries with it more specific literary connotations. A "form" is a "style of expressing the thoughts and ideas in literary or musical composition" ("form, $n$."). The ode is a poetic form, and the connection of the urn to literature is reinforced when the speaker chides the urn for being a "Cold Pastoral!" (45). The somewhat oxymoronic couplings of a silent poetic form and cold pastoral complement each other and highlight the urn's connection to poetry. The speaker's declaration that the urn is a "friend to man" reinforces the connection, for, as Wolfson observes, Keats also calls Milton an "active friend to man" in a March 1818 
letter to James Rice (qtd. in Wolfson 192). In The Odes of John Keats, Helen Vendler notes that the poem begins "with a comparison of the urn with rhyme - to the disadvantage of rhyme" (126) but in the final stanza, the speaker offers no direct words on either art or poetry. Vendler finds that it is the way music and poetry are "temporally experienced" that gives visual art its advantage in this first stanza, but that throughout the poem, the speaker comes to realize that "the mind imposes its own temporality on the stasis of visual art" (126). The urn is therefore pulled back into the temporal realm of poetry, and the final stanza celebrates the relationship between art and poetry. The poem's initial publication in Annals of the Fine Arts further suggests this relationship (Stillinger, Texts 246).

Silence on the urn is the poet's domain. Though the urn is described in terms of "silence" (2) and being "silent" (44), the images it hosts are musical, full of sound and life. The "[b]old lover" woos forever, and his love is forever "fair" (20); the trees exist in eternal springtime (22); the "happy melodist" will be "[f]or ever piping songs for ever new" (24); and the townsfolk are paused in the midst of social activity, as they make their procession together. Only the town, which does not appear on the urn at all, is described as "silent," and because it exists only in the speaker's imagination, it is indicative of his creative power. The creation of an uninhabited, silent town, however, is not enough to act on its own as a celebratory token of creative power, and so in the fifth and final stanza, the speaker pulls himself away from the little town, and out of his creative train of thought, in order to address the urn as a whole once more. He berates the "silent form" because it "tease[s] us out of thought" (44), suggesting that it was the speaker's own creative exploration through questioning that ultimately led to the speaker's need to pull himself away. 
This was not the first time Keats has used the phrase "tease us out of thought." In his March 1818 verse epistle, "Dear Reynolds, as last night I lay in bed," he writes:

Things cannot to the will

Be settled, but they tease us out of thought.

Or is it that imagination brought

Beyond its proper bound, yet still confined, -

Lost in a sort of purgatory blind,

Cannot refer to any standard law

Of either earth or heaven? (76-82)

Reading the two poems together, Waldoff finds that the phrase "tease us out of thought" displays

Keats's acute sensitivity to that point in thought at which unceasing aspiration ironically takes the mind beyond a proper bound toward unexpected images of fierce destruction, of becoming a sod, of an emptied town with silent streets. (142)

In order to come to a complete understanding of the urn, the speaker must pull back, and his creation of the empty, forlorn town is integral to his returning to the urn as a whole in the final stanza. The word "forlorn" is appropriate here, as it is the word that brings the speaker back to himself in "Nightingale," and at this point in "Grecian Urn," the speaker, acting at his creative height, is simultaneously removing himself from the creative mode he had progressed to. Waldoff also draws a connection between "Nightingale" and "Grecian Urn":

Like the poignant image of the Nightingale singing a high requiem to the dead and deaf poet, this image opens out to eternity, evoking the pathos of 
endless longing while recognizing and stressing the futility of further mournful lingering in the experience of silence and absence ... The words “emptied," "evermore," "silent," "desolate," and "return" toll the poet back to his sole self. (141)

The speaker's wakening from thought led to an awakening of the poetic voice in "Nightingale," and similarly, in "Grecian Urn," the speaker is teased out of one train of thought in order to assess the urn as a whole, and articulate his dilemma on a grander scale, which Waldoff describes as "a larger mystery of which the Urn is only a part" (139).

Helen Vendler points out that the scene of the fourth stanza, while "the most sophisticated," is also "the most alienating" (Odes 123). She is speaking of the alienation of the reader, but, in a way, the speaker has alienated himself too, for this is the most communal scene on the urn, and the speaker himself is not a part of it but constructs himself as a sympathetic observer of it. Although he both creates and addresses the town, he does not insert himself in its narrative as he had done in earlier stanzas, for he tells the urn that "not a soul to tell / Why thou art desolate, can e'er return" (39-40). The disappearance of the sociability that had been integral to his creativity may also play a role in the speaker's being pulled out of the world of the little town. In the final stanza, not only the speaker, but all of humankind is connected to the narrative of the urn when the speaker declares that the urn is a "friend to man" (48). Sociability, and a sense of a larger community of readers and spectators of poetry and art, is restored in the affirmative conclusion to the poem.

The recognition of suffering represented by the desolate town is just as important in "Grecian Urn" as it is in "Nightingale," for it leads to the speaker's full appreciation and articulation of the imaginative stimulus offered by the act of reading 
a work of art. Though the images on the urn depict scenes of revelry and music, it is only after the recognition of what has been left out - that is, the still and silent abandoned town - that the speaker can fully understand and appreciate the true beauty of the urn. "Sorrow is Wisdom," Keats writes in a letter to Reynolds, explaining why he now "shall relish Hamlet more than ... ever" (1: 279), and correspondingly, the speaker's understanding of the sorrow inherent in life by reading it onto the urn leads him to a better appreciation of the urn as a work of art. By imaginatively recognizing the suffering and desolation behind the depicted images of the urn, the speaker is able to find the truth in beauty, and it is only after this creative exploration that he is able to voice the urn's message: "“Beauty is truth, truth beauty"” (49).

By understanding and reconciling the silence of "unheard" (11) melodies represented on a "silent form" (44) of art, and the still silence of that which is not represented at all, the speaker does not break the silence, as he does in "Nightingale," but voices it. He gives the urn a voice by articulating its message, "“[b]eauty is truth, truth beauty,"' and in continuing the urn's sentiment and ending the poem with his own message, "that is all / Ye know on earth, and all ye need to know" (49-50), he affirms his own poetic voice in a recognition of the power such an object possesses to excite the imagination. It should be noted that there is no critical consensus as to whether it is, in fact, the speaker who voices the final line, or whether it is part of the urn's larger message. Stillinger lays out the arguments for both sides in "Who Says What to Whom at the End of 'Ode on a Grecian Urn'?” In either case, however, it can be argued that the speaker does affirm his own voice by articulating the urn's. Wolfson points out that the poem "culminates in an answer that can only provoke further questions" (332), and these questions sustain the speaker's creative flow even 
once the poem itself is finished. The circularity of the answer, "Beauty is truth, truth beauty" is not limiting, but rather, through the questions it provokes, affirms the boundless capabilities of the creative reading imagination. Vendler notes that "[i]n other odes, and at the beginning of this ode, Keats is often a passive subject, content to be worked upon by his imaginings" (Odes 145-46), but that because the "interrogatory mode of $U r n$... permits the brain full activity," the speaker can also engage in "consciously intellectual epithets, which attempt a mastery over the object to which they are attached" (146). The speaker assumes this "mastery" at the end of the poem by "giv[ing] the urn language" (Vendler, Odes 147). The urn itself, like a poem, is a man-made work of art that requires a reader or spectator to imbibe it with meaning, and the speaker does this by voicing the urn's concluding epithet. The speaker's full exploration of the urn's meaning culminates in a conclusion to the poem that affirms Keats's own poetic voice in a form as eternal as the silent urn's.

I have focused so far on the creative silence found in Keats's later poetry, but its beginnings can be seen as early as "On First Looking into Chapman's Homer," which ends with an image of Cortez and his men "[s]ilent, upon a peak in Darien" (14). The connection between silence and reading in the sonnet is obvious enough: silence is the speaker's initial reaction to reading - or hearing - Chapman's translation of Homer for the first time. Despite the speaker's tone of enthusiastic wonder in the sonnet, Kenneth M. Mason, Jr. reads the silence at the end of the poem as a signal of the speaker's feelings of "wordless inadequacy" and "isolation" (10). He argues that at the end of the poem, "[h]owever much [the speaker] stares, he cannot describe or express what he looks at. The vision has not only moved him; it has reduced him to silence" (10). In declaring the speaker unable to "express what he looks at," Mason makes the unfounded assumption that the speaker needs to describe 
what he sees. The sonnet, however, is not a detailed account of Chapman's text; it is about the experience of reading it. Mason's focus on the speaker's inability to describe what he sees seems misplaced in a sonnet which celebrates not just what, but how Keats reads.

Mason makes a second contestable assumption in asserting that the experience has "reduced him to silence," for silence is not necessarily a reduction. The speaker is silent as a matter of course: he is silent because he is listening. In "Nightingale" and "Grecian Urn" the silence of listening is an ideal site for imaginative development, and in the Chapman's Homer sonnet it is no different. The speaker's silence is not that of "inadequacy," as Mason suggests, and a comparison with the knight of "La Belle Dame Sans Merci," the prime example of a Keatsian character who does suffer the consequences of the silence of inadequacy, makes this clear. In "La Belle Dame" the knight's silent inadequacy is fundamentally linked to his inability to read, whereas the silence of the speaker of the Chapman's Homer sonnet is one of awe and admiration, which results from a formative reading experience. Although the speaker's silence is "wordless" it reverberates with meaningful significance. The resonance with which the poem ends is evidence of this. After reading the poem, we as readers are also silent, not with an overwhelming sense of our inadequacy to articulate an appropriate response (whether or not we are able to is irrelevant) but silent with awe, appreciation, understanding and respect. What Keats manages so skilfully in this sonnet is a manipulation of his readers so that their reading experience mimics his own. He coaxes us into admiration. The speaker's reaction to hearing Chapman "speak out loud and bold" (8) is also one of awe, appreciation, understanding and respect; it is not a feeling of inadequacy. 
Mason acknowledges both the positive tone of the poem and the fact of Keats's breaking his silence through writing the sonnet, but he does so by arguing that "Keats has displaced his own metaphor" (10) in doing so. When he concludes that "the poetic traveller has done more than look into a silent wonder; he has discovered his own eloquence" (11) the detour into the inadequacy of silence appears unnecessary. While the speaker may discover this "eloquence" through silence, he does not need to triumph over adversity to do so, as Mason's reading suggests. The poem is, in the end, a celebration of reading, friendship, and, not least, Chapman's translation of Homer. The silence it produces is no bad thing at all.

The silence of listening continues, even once Chapman's voice is no longer heard, with a new, more pronounced silence, in which the listener (i.e. the speaker) can digest and explore what he has heard. The very existence of the sonnet tells us that Keats's exploration resulted in an instance of his own voice breaking the silence; it is a product of the reading experience that it documents so beautifully. In this poem, as in others, the silence which accompanies attentive listening, and by extension reading, eventually leads to poetic voice. If the focus of "Nightingale" is the creative power that active listening helps to stimulate, then the Chapman's Homer sonnet illustrates the first step in that process of reading to creation: the listening, or reading, itself. Mason draws attention to the fact that Cortez is separated from his men at the end of the poem, suggesting the "isolation" of the speaker (10). Yet the image of Cortez set apart from his men need not be an image of lonely isolation. Reading the sonnet as an illustration of the first step of the creative process, the image of the speaker-identified Cortez standing alone suggests his readiness, or more accurately, his willingness, to continue the process by turning inward, and focusing on the effect of reading his own mind, as the speaker does in "Nightingale" and "Grecian Urn." 
J. R. Watson emphasizes the silence of wonder rather than the silence of inadequacy in his discussion of the Chapman's Homer sonnet. He states in his reading of "To My Brother George" that "the only appropriate response to a wonder is to be silent in amazement at it" (73). He then extends this to the Chapman's Homer sonnet, and although he, like Mason, takes the silence to be a symbol of the inadequacy of language, he stresses an affirmative inadequacy, arguing that for Keats, reading Chapman's Homer “is a reward of delight and amazement, best expressed in the recognition that words are inadequate" (78). Wonder on its own does not quite characterize the silence either. In fact, an early version of the poem described Cortez's "wond'ring eyes" in line 11, rather than "eagle eyes" (Stillinger, Texts 117). The change suggests that wonder did not adequately convey the piercing poetic vision that the phrase "eagle eyes" implies was awakened by his reading. Watson's analysis relies on George Steiner's 1966 essay, "Silence and the Poet," in which this inadequacy of words is described as an "experience" of "the certitude of a divine meaning surpassing and enfolding ours" (58). Steiner focuses his discussion of the divine on the Christian God, and Watson adapts this for his reading of Keats, taking Keats's "divine" to be represented by "classical myths and legends, then the earlier English poets ... then his contemporaries" (84). To extend this even further, Steiner's "certitude of a divine meaning surpassing and enfolding ours" approximates the inhalation of poetic genius that I discussed in the first chapter. The silence of Chapman's Homer signals something divine, which could very well be associated with the presence of poetic genius.

Despite his positive spin on inadequacy, at times Watson almost aligns with Mason in viewing silence as an obstacle to be overcome by the poet. He refers to language's "limitations," for example, as something the poet "refuses to accept" (78). 
Unlike in Mason, however, these limitations are not to be broken down or overcome. Instead, the poet must "go beyond this" and "reach into the silence" (78). The writing of the sonnet is presumably what becomes of this reaching. In Steiner's essay "reaching" is equated with the poet's ability "to speak with the utmost strength of the word" (58). Neither Watson nor Steiner address listening as part of the progression from reading to silence to creation, but the word "reach" is suggestive of the activity that goes on in the poet's mind during this process. "Reaching" conveys the explorative, questioning mode of "Nightingale," a more sophisticated and extensive form of reading that Keats had not yet articulated at the time of the Chapman's Homer sonnet. In using the phrase "reach into" rather than "reach through" the silence, Watson also captures the inclusiveness of Keats's open reading more adeptly than Mason's analysis does. That he reaches "into" suggests a socialization - a meeting - between the poet and what he has read. Watson is not specific about what the poet reaches for, however. It could be an appropriation of the work he has read, or, more significantly, an exploration of his own silence, which then leads to the creation of the sonnet. Watson writes that "Keats's poetry finds its way out of the silence through a library of books and an art gallery full of pictures" (84). In other words, he breaks his poetic silence through reading.

Keats had announced a poetic silence in “Lines on Seeing a Lock of Milton’s Hair," writing that "[f]or many years my offerings must be hush'd" (32). Both "Milton's Hair" and "On Sitting Down to Read King Lear Once Again” were copied out in Keats's folio edition of Shakespeare, and while the latter announces his intention to prepare for poetic greatness by reading, the former announces the silence that will facilitate his preparation. Though Keats wrote poetry between the King Lear sonnet and the great poetry of the end of 1818 and throughout 1819, these "months 
of preparation," as Walter Jackson Bate refers to them (293), can be seen as a sort of poetic silence - in which his "offerings" are "hush'd" - between the decision to write great things and his accomplishment of it at the end of his career. Keats breaks his silence with the poetic voice that springs out of the great odes, and it is the "wide quietness" (58) of the mind in the first ode, the "Ode to Psyche," that spurs the writing of the rest.

Even in the months before the odes, Keats was beginning to break his poetic silence. He had used the example of listening to a piece of music to describe the "silent Working" of the imagination to Bailey (1: 185), and in "The Eve of St. Agnes," which is the first of the great poems that he composed in 1819, he engages with the tensions between silence and the music that breaks it. When Madeline retires to her room, she makes, in preparation for her ritual, "No uttered syllable" (203). Heidi Thomson points out that the "ritual require[s] absolute silence" (343), and it is interesting to note that although Madeline is silent, her "voluble" (204) heart is another matter,

Paining with eloquence her balmy side;

As though a tongueless nightingale should swell

Her throat in vain, and die, heart-stifled, in her dell. (205-207)

The "eloquence" with which Madeline's heart pains her is rather poetic, and the image of her heart swelling inside her, like a nightingale singing - which Keats would later connect to poetry in "Ode to a Nightingale" - is much like the "teeming" thoughts that have yet to find their release through poetry in "When I have fears." The speaker's fear in that sonnet that he will "cease to be" (1) before this release finds a disquieting parallel image in the simile of the nightingale who "die[s], heartstifled, in her dell." I do not wish to take the comparison too far, but I do want to 
draw attention to the parallel between the silence necessary for Madeline to find her heart's release through the ritual and her eventual awakening by Porphyro, and Keats's poetic silence, which finds its release in the great poetry of 1819 .

Madeline's silence allows her creative imagination to take over as she dreams of Porphyro. While she sleeps, the only sound she makes comes from "her breathing" (246). For Keats, breathing is the essence of mediated reading, and Madeline's dream of Porphyro is mediated by the real Porphyro, who "listen[s] to her breathing" (246) and eventually wakes her with "an ancient ditty" (291). Breathing is also a sign of openness and receptivity in reading, and as Thomson points out, the description of Madeline's "ear touching the melody" (293) in stanza 33 shows that Madeline is receptive to Porphyro's song, for her "ear touches the melody as opposed to the other way around" (346). The melody Madeline hears introduces the aural aspect of mediated reading, and Porphyro's role as a mediator of poetry is made clear when he plays "La belle dame sans mercy" on Madeline's lute (292). Before Madeline is awakened by the song, her role as reader takes on a creative dimension as she dreams, creating an image of Porphyro in her mind. Donald C. Goellnicht describes Keats's "Diligent Indolence" in reading as "that dreamlike state when initially passive reception triggers imaginative reaction" (“Keats on Reading” 197), and Madeline’s dreaming likewise induces creativity. Like the speaker of "Nightingale" who is tolled back to himself by his own thoughts, Madeline is woken, and brought back to reality, by the very man she imagined in her dream; it is as if his presence were dependent on her dreaming of him. Yet at the same time, she is receptive to him, inhaling creative power through his actual presence, and listening to his "ditty," which wakes her. Placing Porphyro and Madeline loosely in the roles of poet and reader, respectively, it is possible to see that their mutual receptivity, the back and forth of creative power 
between them, leads to their ultimate meeting as Madeline wakes, a poet as well, illustrating Keatsian receptivity at its finest.

Keats wrote "The Eve of St. Agnes" in January or February 1819, awakening his poetic voice along with Madeline and writing "La Belle Dame Sans Merci," the great odes, Lamia, and The Fall of Hyperion fragment before the year was over. The last of these great works was "To Autumn." Composed in September 1819, "To Autumn" illustrates the accumulation of Keats's short career of reading in an assertion of poetic power. Ideas of friendship, sociability, and mediation all feature in the poem, and the organic nature inherent in the reading process is reflected in images of ripeness, as well as the music of nature.

A reference to the misty season in the first line provokes the speaker's poetic exploration. James O'Rourke points out that in describing the origin of the poem to Reynolds, Keats writes that he is "all in a mist" (qtd. in O'Rourke 151). Autumn is described as a "[c]lose bosom-friend of the maturing sun" (2), and the sociability of the sun and season "[c]onspiring" (3) together parallels the friendship and sociability that Keats prized for its affect on the growth of his own poetic mind. Just as sociability produces creativity, conspiring actually propels the season's growth, as autumn decides "how to load and bless / With fruit the vines that round the thatcheves run" (3-4). The connection to a vital mediated reading experience is enhanced by the word "[c]onspiring," which, as O'Rourke notes, can be associated with breathing and "the recurring breathiness of the poem's language" (169). He writes that "con/spire means, in its Latin roots, 'to breathe with"” (169). In the Chapman's Homer sonnet, the speaker "breathe[s] the pure serene" of Homer (7), and the inhalation and exhalation of the "pure serene" is equally apparent throughout "To Autumn," aided, perhaps, by the mistiness of the season. 
Autumn has "fill[ed] all fruit with ripeness to the core" (6), and images of abundance, such as the "swell[ing] ... gourd" (7), and the bees' hives "o'er-brimm'd" with honey (11), recall the "teeming brain" of the speaker in "When I have fears." In that sonnet, the speaker fears death taking him "[b]efore my pen has glean' $d$ my teeming brain" (2), but in "To Autumn," the swollen fruit is gleaned; the season itself is a "gleaner" (19). William Flesch, who lays out an argument for identifying autumn with Shakespeare, and then extends this identification to "all of Keats's precursors" (166), argues that the stillness of the images of abundance suggest they are a "suffocating plenitude" (156). He finds the poem "oppressive" (160), weighed down by Shakespeare's influence, until the final stanza. The poem "ends free of Shakespeare," he asserts, "because it ends in a purely natural world from which it has distanced Shakespeare" (161). His argument, however, presupposes a negative relationship with poetic influence. Instead of viewing autumn as representative of Keats's precursors, it is perhaps more useful to think of autumn as the site, or more appropriately, the moment, for the transformation of the accumulation of Keats's reading into his own poetic voice.

At the end of the second stanza, harvested apples become "oozings" (22) emerging through the "cyder-press" (21), suggesting the transformation of the images that had been "teeming" in Keats's mind as they are articulated into his own poetry. This transformation marks the pivotal moment between reading and the articulation of poetic voice, and as such, it is vital to the poetic process. The transformation of harvested apples to cider depends on the earlier ripening and harvesting of the fruit, just as the speaker's poetic transformation hinges on his earlier reading and its accumulation and development in his mind. 
Before the introduction of these transformative "oozings," the stanza is overwhelmed by drowsiness, as autumn is depicted "on a half-reap'd furrow sound asleep, / Drows'd with the fume of poppies" (16-17). In "Nightingale," the poetspeaker's imaginative exploration occurs in a dreamlike state, and his emergent questioning voice even asks, “do I wake or sleep?" (80). In "The Eve of St. Agnes,” Madeline's creativity transpires in her dream, before she wakes up to find that dream a reality. In "To Autumn," the season's drowsiness is physically central to the poem, and it comes only a few lines before the image of transformation, highlighting the importance of that imaginative, dreamlike state to the reading process.

The beginning of the third stanza signals the shift from the expression of Keats's cumulative reading influences to the articulation of the speaker's own poetic voice. With sympathetic confidence, he asks, "[w]here are the songs of spring? Ay, where are they?" (23), and he negates the necessity of an answer by replying, "[t]hink not of them, thou hast thy music too" (24). Wolfson writes that "Keats's brief repetition, 'Ay, where are they?' controls the question, making it a selfconscious repetition of a convention. The poet is able to listen to his voice," she continues, "understanding its ubi sunt? as one of the traditional tones of the season" (365). In "Ode on a Grecian Urn" questioning allows the speaker to read the urn creatively, but here he reads his own poetry through a question, and indeed, the reading of his own work occurs throughout the entire poem. The ideal site for the digestion and transformation of this reading is the "interstanzaic space," as Wolfson terms it (314). Interstanzaic space is a useful term for the spatial dimension it affords the poetic silence between stanzas. It could just as well be termed interstanzaic silence, for the opportunities they provide for stimulation, reflection and transformation of ideas are the same. In "To Autumn," Wolfson writes, these spaces 
"allow certain developing orders of information - syntactic in Stanza 1 and cognitive in Stanza 2 - to wait and weight in the mind before being released into articulation at the start of the next stanza" (362-63). The poet-speaker's digestion of one completed stanza before he continues on to the next suggests that he reads, and responds to, that previous stanza itself. Although the ode also brings in his previous reading, as it is gleaned by the ripeness of the season, by the end of the poem he is reading his own work.

The silence between the second and third stanzas is met with sound; the speaker's affirmation, "thou hast thy music too" (24) is followed by the depiction of that music: "in a wailful choir the small gnats mourn" (27), "full grown lambs loud bleat from hilly bourn" (30), "[h]edge-crickets sing" (31), "[t]he red-breast whistles" (32), and "gathering swallows twitter in the skies" (33). This line once again highlights the importance of accumulation in the poem, as the swallows "gather." Flesch notes that "“[t]he songs of Spring' are the songs of poetic origin ... But Keats offers the consolation that authentic poetic consciousness is autumnal: passive and belated" (162). The maturity of the poetic voice that is to be found in "To Autumn" is the result of the patient accumulation of reading.

The three stanzas of "To Autumn" parallel the stages of the poetic process: reading in the first, the digestion and transformation of poetic power and influence in the second, and the articulation of the reader's own poetic voice in the third. Keats's openness in reading allows the poetic process to develop naturally, and it is fitting that he ultimately articulates his own poetic voice through the natural music of autumn. The poet himself disappears at the end of the poem, and the silence that is left is for us to read. 


\section{Bibliography}

Anderson, Norman A. “Corrections to Amy Lowell's Reading of Keats's Marginalia.” Keats-Shelley Journal 23 (1974): 25-31.

Aske, Martin. Keats and Hellenism: An Essay. Cambridge: Cambridge UP, 1985.

Bate, Walter Jackson. John Keats. Cambridge, MA: Harvard UP, 1963.

Bloom, Harold. Anxiety of Influence: A Theory of Poetry. New York: Oxford UP, 1973.

Bradshaw, John. A Concordance to the Poetical Works of John Milton. 1894. London: Allen and Unwin, 1965.

Carlson, Julie A. "Hazlitt and the Sociability of the Theatre." Romantic Sociability: Social Networks and Literary Culture in Britain, 1770-1840. Eds. Gillian Russell and Clara Tuite. Cambridge: Cambridge UP, 2002. 145-65.

Clarke, Charles Cowden and Mary Cowden Clarke, Recollections of Writers. 1878. Fontwell, Sussex: Centaur, 1969.

Coleridge, Samuel Taylor. The Collected Works of Samuel Taylor Coleridge. Vol. 12. Marginalia: Part 2, Camden to Hutton. Ed. George Whalley. Bollingen Series LXXV. Princeton: Princeton UP, 1985.

Concordance of Shakespeare's Complete Works. 2010. Open Source Shakespeare. 6 October 2009 < http://www.opensourceshakespeare.org/concordance/>.

An Electronic Concordance to Keats's Poetry. Ed. Noah Comet. Romantic Circles. 20 April 2010

<http://www.rc.umd.edu/reference/keatsconcordance/index.html〉.

“exhalation.” The Oxford English Dictionary. 2nd ed. 1989. OED Online. Oxford UP. 10 Sept. $2009<$ http://dictionary.oed.com>. 
Ferris, David. Silent Urns: Romanticism, Hellenism, Modernity. Stanford: Stanford UP, 2000.

Flesch, William. "The Ambivalence of Generosity: Keats Reading Shakespeare." ELH 62 (1995): 149-169. JSTOR. 14 Dec. 2009 <http://jstor.org/search>. “form, n." The Oxford English Dictionary. 2nd ed. 1989. OED Online. Oxford UP. 17 Feb. $2010<$ <ttp://dictionary.oed.com>.

Frosch, Thomas. "Keats’s 'On First Looking into Chapman's Homer.”' The Explicator 62 (2004): 146-50. Literature Online. ProQuest. 15 July 2009 <http://www.proquest.co.uk/>.

Gilfillan, George. "Gilfillan on Keats.” Keats: The Critical Heritage. Ed. G. M. Matthews. London: Routledge, 1971. 302-07.

Gittings, Robert F. John Keats. 1968. Baltimore: Penguin, 1971.

Gleckner, Robert. “Keats’s ‘How Many Bards' and Poetic Tradition.” Keats-Shelley Journal 27 (1978): 14-22.

Goellnicht, Donald C. "Keats on Reading: 'Delicious Diligent Indolence.'” JEGP 82 (1989): 190-210.

---. The Poet-Physician: Keats and Medical Science. Pittsburgh: U of Pittsburgh P, 1984.

"guess, v." The Oxford English Dictionary. 2nd ed. 1989. OED Online. Oxford UP. 23 Mar. $2010<$ http://dictionary.oed.com>.

Harding, Anthony John. "An Ethics of Reading: A Conflicted Romantic Heritage." Keats-Shelley Journal 57 (2008): 45-65.

Hazlitt, William. The Complete Works of William Hazlitt. Ed. P. P. Howe. 21 vols. London: Dent, 1930-34. 
Hunt, Leigh. "Leigh Hunt: Retrospective Views of Keats.” Keats: The Critical Heritage. Ed. G. M. Matthews. London: Routledge, 1971. 249-55.

Jackson, H. J. Marginalia: Readers Writing in Books. New Haven: Yale UP, 2001.

---. Romantic Readers: The Evidence of Marginalia. New Haven: Yale UP, 2005.

Keats, John. Complete Poems. Ed. Jack Stillinger. Cambridge, MA: BelknapHarvard UP, 1982.

---. The Letters of John Keats, 1841-1821. Ed. Hyder E. Rollins. 2 vols. Cambridge: Harvard UP, 1958.

---. "Marginalia.” The Poetical and Other Writings of John Keats. Ed. H. Buxton Forman. Vol. 5. 1939. New York: Phaeton, 1970. 268-322.

---. "On Edmund Kean as a Shakespearean Actor." The Poetical and Other Writings of John Keats. Ed. H. Buxton Forman. Vol. 5. 1939. New York: Phaeton, 1970. 227-32.

---. The Poems of John Keats. Ed. Jack Stillinger. Cambridge, MA: Belknap-Harvard UP, 1978.

Kucich, Greg. "John Keats." Literature of the Romantic Period: A Bibliographical Guide. Ed. Michael O’Neill. Oxford: Clarendon, 1998. 143-66.

Lamb, Charles. "Detached Thoughts on Books and Reading." The Works of Charles and Mary Lamb. Ed. E. V. Lucas. Vol. 2. London: Methuen, 1903. 172-77.

Lau, Beth. "Further Corrections to Amy Lowell's Transcriptions of Keats's Marginalia.” Keats-Shelley Journal 35 (1986): 30-38.

---. Keats's Paradise Lost. Gainesville: UP of Florida, 1998.

---. Keats's Reading of the Romantic Poets. Ann Arbor: U of Michigan Press, 1991. 
Leinwand, Theodore B. "On Sitting Down to Shakespeare Once Again.” The Kenyon Review 24 (2002): 106-23. Literature Online. ProQuest. 9 May 2009 <http://www.proquest.co.uk/>.

Lipking, Lawrence. The Life of the Poet: Beginning and Ending Poetic Careers. Chicago: Chicago UP, 1981.

"listen, v." The Oxford English Dictionary. 2nd ed. 1989. OED Online. Oxford UP. 20 Jan. $2010<$ http://dictionary.oed.com>.

Lockhart, John. "Cockney School of Poetry: No IV.” Blackwood's Edinburgh Magazine 3 (1818): 519-24. Google Books. 22 Aug. 2009 <http://books.google.com/books?id=SGgHAQAAIAAJ>.

Lowell, Amy. John Keats. 2 vols. London: Cape, 1925.

Lowell, James Russell. "Lowell on Keats.” Keats: The Critical Heritage. Ed. G. M. Matthews. London: Routledge, 1971. 358-63.

Magnuson, Paul. Reading Public Romanticism. Princeton: Princeton UP, 1998.

Mason, Kenneth M., Jr. "Keats and the Act of Translation: The Discovery of Voice in 'On First Looking into Chapman's Homer.'” Topic 46 (1997): 7-11.

McNally, Paul. "Keats and the Rhetoric of Association: On Looking into the Chapman's Homer Sonnet.” JEGP 79 (1980), 530-40.

Milton, John. The Major Works. Ed. Stephen Orgel and Jonathan Goldberg. Oxford: Oxford UP, 1991.

“mist, n." OED Online. Mar. 2010. Oxford UP. 17 Sept. 2009 $<$ http://dictionary.oed.com>.

“mist, $n$. "” OED Online. Mar. 2010. Oxford UP. 17 Sept. 2009 $<$ http://dictionary.oed.com>. 
MLA International Bibliography. 2010. EBSCO. 4 May 2010

$<$ http://search.ebscohost.com>.

Muir, Kenneth. "Keats and Hazlitt." Proceedings of the Leeds Philosophical and Literary Society 6 (1951): 534-50. Rpt. in John Keats: A Reassessment.

Kenneth Muir. 2nd ed. Liverpool: Liverpool UP, 1969. 139-58.

Mulrooney, Jonathan. "Keats in the Company of Kean." Studies in Romanticism 42 (2003): 227-50. Literature Online. ProQuest. 6 May 2010

$<$ http://www.proquest.co.uk/>.

Murry, John Middleton. Keats and Shakespeare: A Study of Keats' Poetic Life from 1816 to 1820. London: Oxford UP, 1925.

Newlyn, Lucy. Paradise Lost and the Romantic Reader. 1993. Oxford: Oxford UP, 2004.

---. Reading, Writing and Romanticism: The Anxiety of Reception. Oxford: Oxford UP, 2000.

O'Rourke, James. Keats's Odes and Contemporary Criticism. Gainesville: UP of Florida, 1998.

Pollack-Pelzner, Daniel. "Revisionary Company: Keats, Homer, and Dante in the Chapman Sonnet.” Keats-Shelley Journal 56 (2007): 39-49.

“read, v." OED Online. Mar. 2010. Oxford UP. 15 Jan. 2010 $<$ http://dictionary.oed.com>.

Richardson, Joanna. The Everlasting Spell: A Study of Keats and his Friends. London: Cape, 1963.

Ricks, Christopher. Keats and Embarrassment. Oxford: Clarendon, 1974.

---. “Keats's Sources, Keats's Allusions.” The Cambridge Companion to Keats. Ed. Susan J. Wolfson. Cambridge: Cambridge UP, 2001. 152-69. 
Roe, Nicholas. Keats and the Culture of Dissent. Oxford: Clarendon, 1997.

Rollins, Hyder Edward, ed. The Keats Circle: Letters and Papers 1816-1878. 2 vols. Cambridge, MA: Harvard UP, 1948.

Russell, Gillian and Clara Tuite. "Introducing Romantic Sociability.” Romantic Sociability: Social Networks and Literary Culture in Britain, 1770-1840. Eds. Gillian Russell and Clara Tuite. Cambridge: Cambridge UP, 2002. 1-23.

Rzepka, Charles. “'Cortez - or Balboa, or Somebody Like That': Form, Fact, and Forgetting in Keats’s ‘Chapman’s Homer' Sonnet.” KSJ 51 (2002): 35-75.

Sharp, Ronald A. "Keats and Friendship." The Persistence of Poetry: Bicentennial Essays on Keats. Eds. Robert M. Ryan and Ronald A. Sharp. Amherst: U of Massachusetts P, 1998. 66-81.

Shears, Jonathon. The Romantic Legacy of Paradise Lost: Reading Against the Grain. Burlington: Ashgate, 2009.

Sperry, Stuart. Keats the Poet. Princeton: Princeton UP, 1973.

Spurgeon, Caroline F. E. Keats's Shakespeare: A Descriptive Study. 1928. Oxford: Clarendon, 1966.

St. Clair, William. The Reading Nation in the Romantic Period. Cambridge: Cambridge UP, 2004.

Steiner, George. "Silence and the Poet." 1966. Language and Silence: Essays 19581966. London: Faber, 1967. 55-74.

Stillinger, Jack. "John Keats.” The English Romantic Poets: A Review of Research and Criticism. Ed. Frank Jordan. 4th ed. New York: MLA, 1985. 665-718.

---. Reading “The Eve of St. Agnes”: The Multiples of Complex Literary Transaction. New York: Oxford UP, 1999.

---. The Texts of Keats's Poems. Cambridge, MA: Harvard UP, 1974. 
---. "Who Says What to Whom at the End of 'Ode on a Grecian Urn'?" PMLA 73 (1958): 447-78. Rpt. in “The Hoodwinking of Madeline” and Other Essays on Keats's Poems. Urbana: U of Illinois P, 1971. 167-73.

"synaesthesia." The Oxford English Dictionary. 2nd ed. 1989. OED Online. Oxford UP. 15 May $2010<$ http://dictionary.oed.com>.

Thomson, Heidi. 'Eavesdropping on 'The Eve of St. Agnes': Madeline's Sensual Ear and Porphyro’s Ancient Ditty.” JEGP 97 (1998): 337-51.

Vendler, Helen. Coming of Age as a Poet. Cambridge, MA: Harvard UP, 2003.

---. The Odes of John Keats. Cambridge, MA: Belknap-Harvard UP, 1983.

Waldoff, Leon. Keats and the Silent Work of the Imagination. Urbana: U of Illinois P, 1985.

Watson, J. R., "Keats and Silence.” Keats: Bicentenary Readings. Edinburgh: Edinburgh UP, 1997. 71-87.

Webb, Timothy. "Homer and the Romantics." The Cambridge Companion to Homer. Ed. Robert Fowler. Cambridge: Cambridge UP, 2004.

White, R. S. Keats as a Reader of Shakespeare. London: Athlone Press, 1987.

Wittreich, Joseph Anthony, Jr., ed. The Romantics on Milton: Formal Essays and Critical Asides. Cleveland: P of Case Western Reserve U, 1970.

Wolfson, Susan. The Questioning Presence: Wordsworth, Keats, and the Interrogative Mode in Romantic Poetry. Ithaca: Cornell UP, 1986. 